\title{
WHERE TO MOVE? EVALUATING THE POTENTIAL OF BMO FIELD AND VARSITY CENTRE TO HOST THE TORONTO ARGONAUTS
}

\author{
by \\ Jake Mark Garland \\ Bachelor of Arts Honours, University of Guelph, 2012 \\ A Major Research Paper \\ presented to Ryerson University \\ in partial fulfillment of the requirements for the degree of \\ Master of Planning \\ in \\ Urban Development
}

Toronto, Ontario, Canada, 2015

(C) Jake Mark Garland 2015 


\section{Author's Declaration for Electronic Submission of a MRP}

I hereby declare that I am the sole author of this MRP. This is a true copy of the MRP, including any required final revisions.

I authorize Ryerson University to lend this MRP to other institutions or individuals for the purpose of scholarly research

I further authorize Ryerson University to reproduce this MRP by photocopying or by other means, in total or in part, at the request of other institutions or individuals for the purpose of scholarly research.

I understand that my MRP may be made electronically available to the public. 


\title{
WHERE TO MOVE? EVALUATING THE POTENTIAL OF BMO FIELD AND VARSITY CENTRE TO HOST THE TORONTO ARGONAUTS
}

\author{
(C) Jake Mark Garland, 2015 \\ Master of Planning \\ in \\ Urban Development \\ Ryerson University
}

\begin{abstract}
The Toronto Argonauts are the oldest continuously running professional football team in North America and a storied franchise within the Canadian Football League. However, they are also a team facing vagrancy, with their lease at Rogers Centre expiring on December 31, 2017 and have historically had trouble-selling tickets at this locale. The team is now looking to play in a smaller established venue that is more realistic to fill and such stadiums suggested have included BMO Field and Varsity Centre. Therefore, the research within this paper addresses the gap in the planning knowledge of which of these two stadiums should be chosen to move the team to from evaluations that include redevelopment cost, site location, accessibility, and a surrounding land use. The research highlights that Varsity Centre has the greatest potential, while also providing a set of recommendations for either site to optimize the potential to host the team.
\end{abstract}

Key words: Toronto Argonauts, Stadium Evaluation, BMO Field, Varsity Centre 


\section{Acknowledgements}

I would like to acknowledge Professor David Amborski for his supervision during the undertaking of my research. Your input and recommendations have further developed my research topic. Next I would also like to recognize Dr. Jaclene Begley for being my secondary supervisor whose feedback has been helpful during this process.

A large thanks to my family. Mom and Dad, thank you for your constant love and selfless actions that have never gone unnoticed. Without you I would not have been afforded the opportunities I have had while growing up and the work ethic instilled within me to succeed.

Finally, to Julia, your unwavering love and support is unparalleled. There were some trying times during this program, but I could always count on you for the strength I needed to help keep me going. 


\section{Table of Contents}

Author's Declaration for Electronic Submission of a MRP .............................................ii

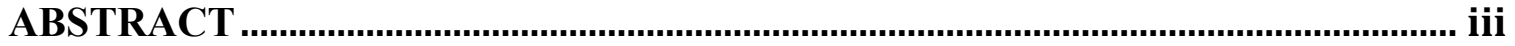

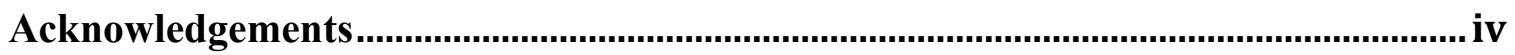

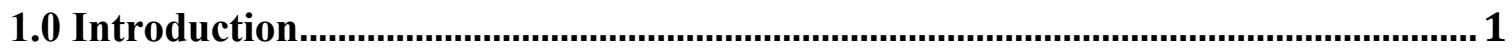

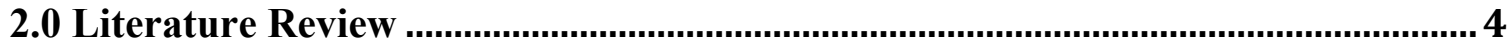

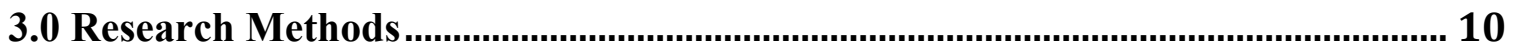

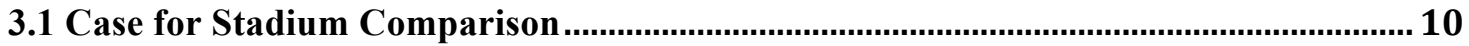

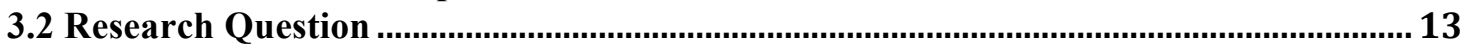

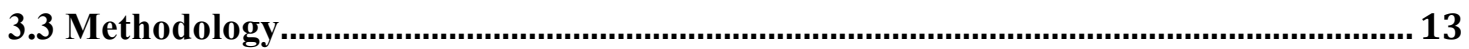

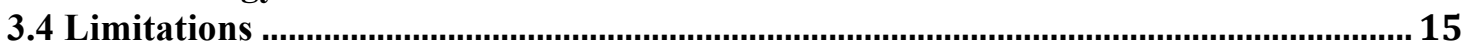

4.0 Redevelopment Cost Evaluation ....................................................................... 17

4.1 Financial Cost to Redevelop Current Stadium on Site................................................... 17

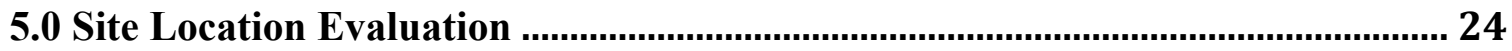

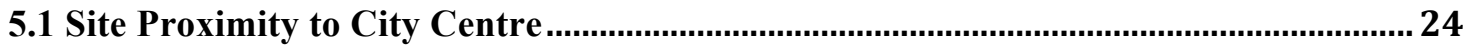

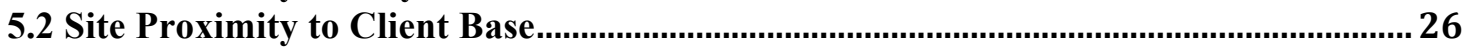

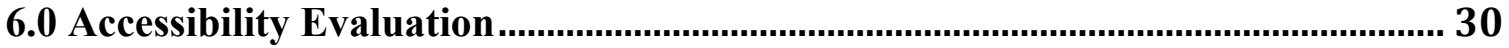

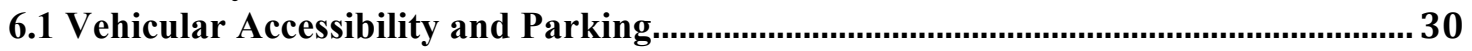

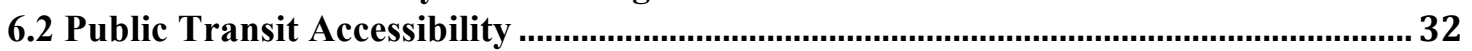

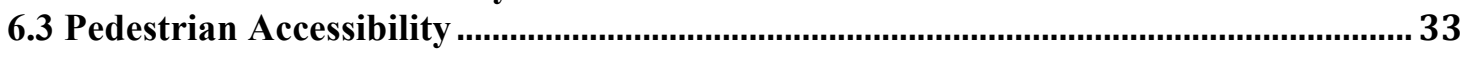

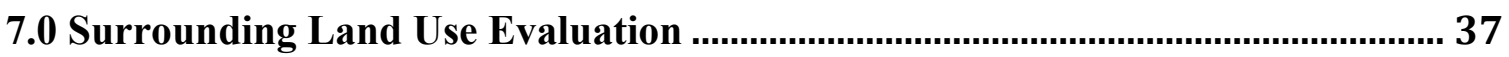

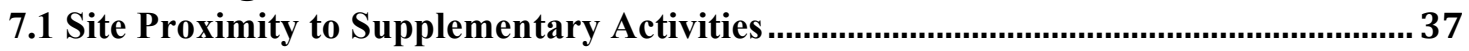

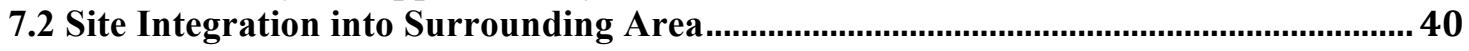

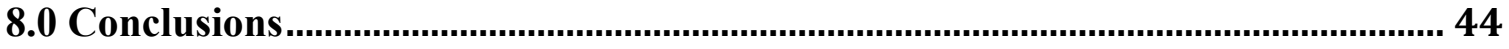

8.1 Redevelopment Cost Conclusion ................................................................................. 44

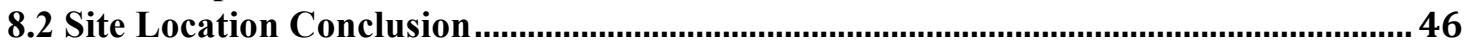

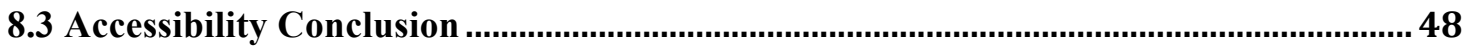

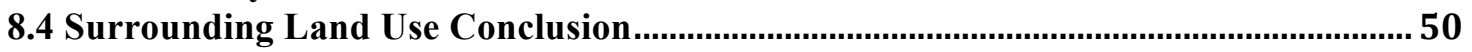

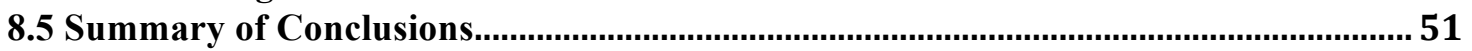

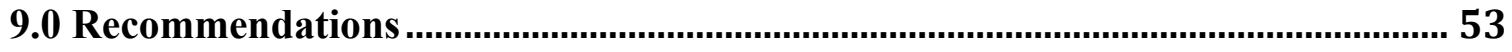

References ...................................................................................................................... 55

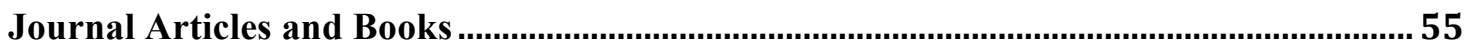

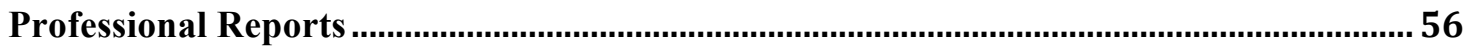

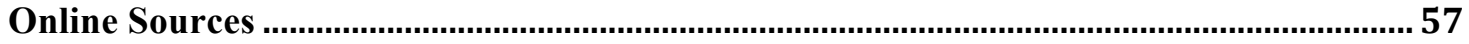

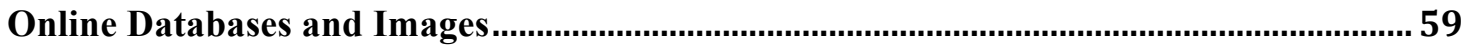




\section{List of Tables}

Table 1: Comparison of Sites and Redevelopment Characteristics.................23

Table 2: Representative Population in Relation to BMO Field Location...........28

Table 3: Representative Population in Relation to Varsity Centre Location........29

Table 4: Concluding Summary of Sites Based on Evaluations.....................52 


\section{List of Figures}

Figure 1: BMO Field, Exhibition Place, Toronto, Ontario..........................18

Figure 2: Varsity Centre, University of Toronto, Toronto, Ontario..................20

Figure 3: Location of BMO Field and Distance from the City Centre.................25

Figure 4: Location of Varsity Centre and Distance from the City Centre.............26

Figure 5: Potential Onsite Parking Surrounding BMO Field.......................31

Figure 6: Potential Onsite Parking Surrounding Varsity Centre.....................32

Figure 7: Representative 15-Minute Walk Radius Surrounding BMO Field.........35

Figure 8: Representative 15-Minute Walk Radius Surrounding Varsity Centre.....36

Figure 9: Surrounding Land Use within a 15-Minute Walk Catchment of BMO

Field.................................................................................38

Figure 10: Surrounding Land Use within a 15-Minute Walk Catchment of Varsity

Centre.....................................................................................40

Figure 11: Illustration of the Built and Unbuilt Space Surrounding BMO Field.....42

Figure 12: Illustration of the Built and Unbuilt Space Surrounding Varsity

Centre. 


\subsection{Introduction}

The Toronto Argonauts are the oldest continuously running professional football team in North America (Scianitti, 2014) and are one of the most storied franchises in the Canadian Football League (CFL). However, it is also a team facing vagrancy, with their lease at Rogers Centre expiring on December 31, 2017 (Ralph, 2013). The team has also historically had trouble-selling tickets to fill the large stadium, with the average attendance over seven home dates in 2014 being just 17,300 (Stinson, 2014b). This being said team is looking to play in a smaller established venue that is more realistic to fill (Ralph, 2013) and would be more financially feasible than any notion of building a new stadium at this present time.

The franchise has made their home the City of Toronto during the entirety of their 140 plus year history. Although their playing field location has changed many times since their inception and the team was very much a success within the city, moving between stadiums only out of necessity. The team was inaugurated in 1873, as the Toronto Argonauts Football Club, as part of the Argonaut Rowing Club, using the double blue colours of Oxford and Cambridge for club members who were originally rugby football enthusiasts (Toronto Argonauts, n.d.b).

Their first stadium was Rosedale Field that was located at Mount Pleasant Avenue and MacLennan Avenue. It was used by the team between the years of 1874-1897 and 1908-1915 (Toronto Argonauts, n.d.a). The Argonauts then moved to Varsity Stadium, located at Bloor Street and Devonshire Place, on the University of Toronto campus. The team played there during three different periods found between 1898-1907, 1916-1924, and 1925-1959 (Toronto Argonauts, n.d.a). Capacity of the stadium varied with time, but 
peaked at about 22,000 in the 1950s. Although it had not hosted a meaningful CFL game in almost half a century, it was demolished in 2006 and rebuilt as Varsity Centre, and recently held preseason Argonauts games sin 2013 and 2014. It also still holds the record for the number of times any stadium has hosted the CFL championship game, the Grey Cup (Rush, 2014).

From Varsity Stadium the team then moved to the Canadian National Exhibition Stadium that was a former multi-purpose facility at Princess Boulevard and Ontario Drive on the Exhibition Place grounds in Toronto. When the Argonauts moved for the 1959 season, a smaller bleacher section was added along the south sideline to allow the stadium to seat 33,150 (Toronto Argonauts, n.d.a). In 1999, the stadium was demolished to be used for parking until 2006 and Bank of Montreal (BMO) Field, a soccer-specific stadium was built on the site in 2007 (Toronto Argonauts, n.d.a).

The team played at this location until 1989, when it moved to the SkyDome, now Rogers Centre, a 53,000 seat multi-purpose stadium in the downtown situated at Front Street and Blue Jays Way. It currently continues to be the home of the Argonauts, however, the success of the team to draw fans has waned during their time at the Rogers Centre. In 2013 news was announced from Rogers Communications, the owner of Roger Centre, that the teams lease at Rogers Centre is set to expire on December 31, 2017 (Ralph, 2013).

This has left a team, which has had troubles selling tickets for numerous years, in an uncertain state and looking for an alternative venue to play their home games. Despite these struggles the, it seems all involved with the team, the CFL, and the City of Toronto agree they are needed, in fact the CFL's strongest television ratings come from games 
involving the Argos. City of Toronto's ex-Mayor has also been a large proponent, along with other city officials, of finding the team a new home and in July 2013 stated, "We can either work with $\mathrm{U}$ of $\mathrm{T}$, we can work with BMO (Field) or maybe we can work with Downsview or Woodbine," (CBC News, 2013). Those involved with the team hope that game attendance will follow in the television ratings footsteps as the future of the team becomes clearer in 2017 through planning to relocate the team to a new revamped stadium (Rush, 2014).

Thus, the research that is proposed within this paper will address this gap in the planning knowledge of where to relocate the Toronto Argonauts football team from the chosen two stadiums, BMO Field and Varsity Centre at the University of Toronto, from the four aforementioned sites. These two stadiums will be compared based on the evaluated criteria that were determined through conducting an intensive literature review and include redevelopment cost, site, accessibility, and a surrounding land use. It is the hope that the outcome of this research will demonstrate the which site has the greater site to be the new home of the Toronto Argonauts professional football team, while also allowing for the establishment of a set of recommendations that would be of benefit to the City of Toronto with either stadium if selected. 


\subsection{Literature Review}

Canadians love sports, it has become a part of the Canadian society, as fans watch their home teams, from professional hockey, basketball, baseball, and football. Partaking in these events generates a great deal of excitement and local pride for citizens, some would even argue more so than most any other kind of event in town (Kemp, 2009; Bennett, 2012). Nelson (2002) even depicts that city officials hold professional sports teams in a similar regard to the prestige gained by having museums and symphonies in and are therefore a critical element of a metropolitan area's economic and social vitality. This reasoning in itself can be motivation enough to illustrate as to why cities stick with their teams through the good times and the bad times. In fact, cities with failing teams are even willing to go to great lengths to ensure that teams will stay and not move to another locale, that is intensified due to the limited stock of possible major league franchises (Friedman \& Mason, 2004). Most often the means to do so is to build or renovate facilities for the team in hopes of keeping them, which is often the most visible way a city can show its commitment and support to the team (Kemp, 2009). Governments will spend a large quantity of money on major league sports facilities and can be done using public funding for these professional sports facilities (Long, 2005).

Swindell and Rosentraub (1998) wrote, that during the early years of professional sports through the 1950s, most teams played home games in privately owned stadiums. Teams wanted little involvement from the public sector, however, later publicly funded facilities became more of the common norm due to the impacts these teams were to have on the fans that lived in the city. Local professional sports teams may also provide public consumption benefits to members of a community. Public consumption benefits are those 
that residents can receive without attending games. Following, discussing, and debating the ups and downs of the local team can provide benefits for community residents. Local residents also see the presence of high profile sports as a source of civic pride and national reputation (Swindell \& Rosentraub, 1998; Davies, 2010). This can enhance the arguments among cities and their officials to become involved in supporting professional sport teams and new stadium development is that new sporting venues would serve as a catalyst for growth in economic development, tourism, and community development (Scott \& Turner, 2010; Mason, 2012). Although sport remains only a part of what makes a city unique or economically viable, investing in sports stadiums or arenas can be among the most expensive infrastructure decisions that city leaders can make (Mason, 2012).

Costs and the financing of the facilities are some of the most common factors when determining to plan new or renovated sports facilities. This is due impart to a belief among city officials that the use of sport can address regeneration objectives to specific facility locales through the creation of economic development, increased employment, and social benefits (Mason, 2012; Propheter, 2012). It must also be realized that stadium proponents are aware of the financial benefits and costs that need to be argued for new professional sports facilities in order to garner popular support, but they are also becoming more sophisticated in the arguments they are making to gain support for them (Mason, 2012).

However, for more than four decades now, scholars have assessed the value of professional sports teams to local and regional economies and despite local support for new sports facilities as a means of promoting economic development, many economists and scholars are skeptical of the supposed economic benefits they bring to a community 
(Scott \& Turner, 2010; Rosentraub, 2006). Moreover, Propheter (2012) found in his research that most studies promoting subsidy are usually completed before stadium construction even begins, basing projections on subjective data such that speculates about economic generation once the stadium is built. Furthering this argument, empirical research has generally demonstrated that new stadiums do not serve as catalysts for local economic growth and can lead to economic stagnation (Chapin, 2004; Groothuis, Johnson, \& Whitehead, 2004); Coates \& Humphreys, 2006; Scott \& Turner, 2010; Galily, Yuval, \& Eli, 2012). In fact, most economic studies on the impact of new or redeveloped stadiums do not account for public goods and frequently understate the full benefit of the team to local residents (Noll \& Zimbalist, 1997). Though as time passes, this information on costs and benefits has become common knowledge and this has lead to more and more Canadian cities experiencing significant cutbacks in government subsidies for these professional sports (Lenskyi, 2004).

Due to the cost of financing such facilities and that their economic impacts are underwhelming, support for financing a facility just to have one in a city has waned and more focus has begun to be placed on planning them to offer the utmost societal benefits. Even still, these benefits need to be further explored when proposing new or redeveloped facilities for professional sports franchises. As Rosentraub (2010) found, cities that have actively integrated their sport facility projects into a broad urban development agenda tend to find more returns on their investment. Therefore, it has become more inherent in the many decisions facing these franchises and their cities regarding newly planned or redeveloped facilities to focus more on the quality of location to determine the facilities viability to host a professional sports team and not solely on the financing costs 
(Newsome \& Cormer, 2000). To this extent, local governments, private organizations, and public officials are now more often looking to urban planners to assist with facility development techniques to address and review the encouragement or discouragement of the development and redevelopment of professional sports stadiums among different city venues (Kemp, 2009).

An example of a planning technique used by planners is to adequately determine the stadium's site location within the city (Thornley, 2002). The property development imperative of location, location, location, illustrates how important geographical location is for the value of any proposed investment and its projected benefits (Burke \& Evans, 2010). Preferable is a stadium in the city centre, near the central business districts. The major attraction of this location is that it can draw upon the good public transport facilities available and generate synergy with exiting central area uses. In major North American cities such a location is often encouraged, as it can become a proponent of the city's economy. Locating the stadium in downtown or city centre locales allows of the incorporation of new team facilities to bring a sense of place upon the urban landscape for local residents, being portrayed as a city as one that is, vibrant, diverse, exciting, and world class (Delaney \& Eckstein, 2007). If integrated correctly, these stadiums can become some of the most celebrated buildings within the community and create civic pride (Duquette \& Mason, 2008; Rosentraub, 2006). Due to these functions, a professional sports facilities located in a downtown is also considered to help draw greater population numbers, be in close proximity to established population locales, and expected growth targeted areas of a city, attracting of more diverse socioeconomic groups and can help and can help improve public transport to the area (Thornley, 2002; Mason, 
2012).

Another planning technique that can be used by planners is to demonstrate the accessibility of the stadium's location within the city. This is particularly true for professional sports stadiums that are reliant on the access of patrons from different urban catchments (Burke \& Evans, 2010). As Bain (1994) noted this is due to the fact that travel costs are borne by patrons once a stadium is built, there is a clear marketorientation for transportation influencing location decisions. Locating a professional sports facility in the city centre or in close proximity allows for it to be easily accessible to a pedestrian client base before and after games (John, Sheard, \& Vickery, 2007; Coates \& Humphreys, 2006). Burke and Evans (2010) also noticed that few transport concern studies placed attention on the transport and land use relationships of professional sport stadiums. However, they felt that with the traffic and parking issues cities are faced with today being most problematic for city centre stadium development, that more attention needs to be placed on the travel experiences sports fans could face. Strengthening this argument is that walking for transport within urban development is gaining attention and the smart growth and new urbanism principles are focusing on creating walkable, denser built environments within a 5-10 minute walking proximity to services or features of interest, even walking further to get to certain kinds of destinations depending on the circumstances (Badland, White, MacAulay, Eagleson, Mavoa, Pettit, \& Giles-Corti, 2013). This is believed to be especially true in a time when public transit and alternative modes of transportation are becoming greater priorities and less is placed on private automobile ownership. Also, for those travelling to a venue from farther distances need adequate means to do so with vehicles and this can be hard to adequately accommodate 
for within city centres, but must be accounted for when developing sports facilities.

The final example of a planning technique to be implemented by planners is to explore that the stadium's location is in terms of its proximity to ancillary numerous land uses. Attending professional sporting events can be a socializing experience and stadiums found within a city centre provide citizens with the most accessible location in which to enjoy sporting events to their fullest potential (Coates \& Humphreys, 2006). Once at these stadiums, patrons can take advantage of other things near them such as stores, restaurants, and other points of interest. Therefore, by locating professional sports stadiums downtown, nearby merchants in the vicinity of the stadium will benefit from pregame and postgame activities. Once in the city centre to attend a sports event, fans are more likely there than elsewhere to patronize stores, spend the evening in hotels, and visit other attractions such as museums and art galleries. Commercial facilities in these locations also provide patrons the greatest opportunity to spend money before, during, and after events (Bain, 1994). Also, with a greater number of surrounding land uses creates the opportunity for consumers to experience space uniquely and have access to a variety of choices and diversity within the urban landscape (Nelson, 2002).

Yet, there is still considerable disagreement on whether all constructed sports facilities indeed can provide these types of social benefits that are promised and further research on a case by case needs to be completed to find evidence to support these claims made by city authorities and sporting organizations, especially those involved in public funding for sport-related infrastructure (Davies, 2010). 


\subsection{Research Methods}

\subsection{Case for Stadium Comparison}

There is a belief among the Toronto Argonauts team executives, that when looking to move the franchise, that a smaller stadium would create an improved atmosphere at the games. The belief is that a large stadium, such as the Rogers Centre, that holds 50,000 people while only an average of 17,300 fans attending a game causes the venue to lose its sense of intimacy and experience for a fan (Stinson, 2014b). This in turn causes the potential fan to lose the sense of urgency to be present at a game since they feel that they could show up for any game with the demand for tickets being low. There is also the fact that the team needs its attendance to be at least 22,000 to satisfactorily supply the team revenue (Stinson, 2014b) and a new, smaller stadium venue would create a this sense of urgency and conversation piece for potential fans, whom are looking for a way to reconnect with the team.

Knowing that the team is struggling to draw the needed supporters to their homes games in recent years, while also trying to determine a new site, it would be practical to house the team in a previously constructed stadium that would take less of a financial commitment and still produce the required numbers of seats for patrons to be able to view the game. City of Toronto's officials are in favour of finding the team a new home, and in July 2013 were offering to work with University of Toronto and BMO Field, among other potential sites (CBC News, 2013). Each location has its own positives and negatives to take into account. Since this time the certainty of securing a new stadium location has not progressed into any certainties, except some being more attainable than not. 
At this current time two of the aforementioned sites seem to be the most established for discussion as they are most closely linked to the team for various reasons. These include the smaller stadiums of City of Toronto owned BMO Field and University of Toronto owned Varsity Centre. Most publicized thus far, has been that BMO could be the answer and in the fall of 2013 Maple Leaf Sport and Entertainment (MLSE) approached the City of Toronto with a proposal to make beneficial changes to the stadium to be able to host Toronto Argonaut home games among others:

- Increase the permanent seating capacity to 30,000 and allow for an additional 10,000 in temporary seating capacity for special events.

- Reconfigure the field so that the stadium can host Canadian Football League (CFL) games (City of Toronto, 2014).

MLSE proposed an expansion to capacity in the stadium and this renovation would also provide the stadium with the ability to host CFL games at BMO Field, which had become an important objective for the city. On April 3, 2014 City of Toronto Council voted a resounding 39-3 in favour of supporting a \$10 million financing loan to MLSE for its proposal to renovate and expand BMO Field (Shum, 2014). It would be a threephased renovation plan (Rubin, 2014), to see the stadium adequately altered to field the Toronto Argonauts (Shum, 2014). However, there was and continues to be an indifference on funding, which is leaving the third phase of the plan in a state that it is less likely that it will be followed through with.

Still, if BMO Field should not play out as the new stadium out, the case for Varsity Centre to host the team becomes of greater relevance. Then known as Varsity Stadium, it had been a central figure to the CFL and Toronto Argonauts for decades and was a regular host for the Grey Cup games. As recently as 2004, the team had discussed 
the possibility of moving to this location and Varsity Centre once it was rebuilt in 2006, to now accommodate 25,000 fans. This has always kept this stadium in the discussion of possible new location for the team. Even as recent as 2011, the University of Toronto and the Toronto Argonauts held discussions about the possibility of expanding Varsity Centre, but in both instances the plans were never fully realized due to financing, political, and not in my backyard (nimbyism) problems surrounding the University of Toronto land (Blair, 2012). Also, of interest to note in favour of this proposed site is the potential partnership between the CFL and a Canadian University, that is similar to circumstances that had occurred previously. The Montreal Alouettes, another CFL team, have succeeded at a smaller venue at McGill University since moving there in 1998 (Rush, 2014).

These reasons provided above plus the team having recently concluded the second straight year where they played a scheduled a pre-season game at the stadium, show cause for the argument that this stadium is equally as appealing to relocate the franchise to. Based off these successes, it has begun to demonstrate to the team what benefits a more intimate environment can provide and marry the history of the team with this city location that hosted Argonaut games for over 50 years (Rush, 2014).

Combining the uncertainty for BMO Field to have the proposed third phase of the renovation completed and the ever-present connection of the team to Varsity Centre with its beneficial prospect displayed through the two recent successful games it held has opened the topic to theoretical possibility. With both locations garnering speculation of a place to relocate the team, a comparison can be completed between the two facilities to see which would be the superior locale based on planning measures to attract fans. 


\subsection{Research Question}

Which stadium, BMO Field or Varsity Centre, has the greater potential to become the new home stadium of the Toronto Argonauts based on the evaluated criteria of redevelopment cost, site location, accessibility, and surrounding land use?

\subsection{Methodology}

In order to answer the research question formulated above and address the gap in knowledge of what stadium the Toronto Argonauts team would be most beneficial within the city, this report has provided an intensive literature review and uses it to help further focus the research of these two stadiums to host the team. Due to the professional football team being required to vacate the Rogers Centre, the city's long historic association with the Argonauts franchise, and the push from team proponents to find the team a new home within the City of Toronto, BMO Field and Varsity Centre become the focus of the proposed research as neither are definitive enough to securely proclaim it the new location within the city.

As there is no decisive answer on where to relocate the team to between the two different stadiums suggested, further research needs to be conducted to better in determine how each proposed site would be as the new home facility. To attain greater certainty of each stadium's potential to do so, case studies are conducted between the proposed sites. Case studies are a sensible strategy when the focus is within some reallife context and are also a common research strategy in community planning issues (Yin, 2003)

BMO Field and Varsity Centre were chosen for a number of reasons, that include both having historic ties to the team playing in each location, BMO Field being the most 
widely speculated stadium to host the team, and Varsity Centre had been considered as the permanent home for the team to move into only a decade ago, while it has currently hosted preseason home games the past two seasons along with past. These reasons provided on each facility's connection to the team and allow for a justifiable cause to be made to make the desired comparison on the potential of each to host the team.

Provided from the literature review completed, comparing and contrasting these two sites would be most beneficial in terms of the redevelopment cost, specific site location, accessibility, and surrounding land uses as these are very important evaluation criteria to be taken into consideration when planning professional sports stadiums. They provide the study with the basis to use planning techniques to compare, how successful each stadium would potentially be to serve at the home of the Toronto Argonauts and make recommendations accordingly. A redevelopment cost evaluation calculates the potential economic costs that will be associated to either stadium becoming the host facility of the Toronto Argonauts. Secondly, a site location evaluation examines each facility's site and its location within its respective area of the city centre. An accessibility evaluation measures the stadium's connections to the existing infrastructure for private vehicles, public transit, and pedestrians. Finally, a land use evaluation assesses how the surrounding area impacts the facility and the surrounding land uses. The reliability of these four evaluation criteria add to the credibility of this study because they can be applied beyond the scope this initial comparison of these two sites and could be repeated when applied to researching other potential sites within the City of Toronto.

Furthermore, the research and evaluations of BMO Field and Varsity Centre were completed through the use of academic journals and books, planning reports, newspaper 
articles, online sources, and site visits. A literature review analyzed an extensive list of journal articles and books in order to put together a list of evaluation criteria and gain the knowledge necessary to evaluate each criterion. Planning reports were also used to help further evaluate the data collected for the identified as well. Newspaper articles and online sources were used in order to write case descriptions. Finally, site visits to both locales were completed to inventory land uses in the vicinity of the stadium site and to gain a better understanding of each stadium's current functional dynamic. Using these four criteria to compile and compare data of how well each stadium would function as the new Toronto Argonauts stadium within their specific locations. The evaluation criteria within the research method provide a well-defined procedure that would allow the research to be emulated to assist similar projects.

\subsection{Limitations}

This study has methodically evaluated BMO Field and Varsity Centre according to a set of defined evaluation criteria, however, in doing so there are still limitations within the research methodology that need to be accounted for.

Evaluated was how each stadium will theoretically function in its city centre location of Toronto as the new home of the Toronto Argonauts football team. However, there was a biased selection process of the stadiums studied, this was due to a number of existing ties between both teams to validate the use of both locations. Such connections include both being located in the city centre of Toronto, each facility is located in an area that has a historic connection to the team, and both stadiums would need to be renovated to accommodate the capacity to house the team.

Another limitation within the study is demonstrated because, although this study 
has extensively reviewed the potential for both stadiums to house the struggling Toronto Argonauts franchise, this is only an initial form of investigation into the topic of two of the four aforementioned potential sites. To provide a more comprehensive and conclusive research procedure, this study could be applied to the other locales mentioned previously to provide a more thorough representation of potential sites and a greater opportunity to relocate the team to the most well suited site.

There are also limitations found in the set of four evaluations used, redevelopment cost, site location, accessibility, and land use, for the study of both potential stadium locations. Though these are significant evaluation that much of the literature reviewed touches upon as important, this most certainly does not exhaust all functional elements when determining stadium location within a city centre. Although as mentioned it does emphasize some of the most mutually shared elements discussed across a swath of academics in the field of stadium planning.

Finally, the evaluation of the redevelopment cost criteria completed was hypothetical. Although there has been a proposal to redevelop BMO Field, no such plan has come forward for Varsity Centre. This weakens the argument for Varsity Centre due to the uncertainty of any potential redevelopment costs proposed when comparing the two sites. 


\subsection{Redevelopment Cost Evaluation}

The following section discusses the potential redevelopment costs that will be associated to both either stadium becoming the host facility of the Toronto Argonauts. Factors contributing to this evaluation will be the overall cost of each project, where the funding will come from, and the potential work needed to be completed to make the facility suitable to host CFL football games for the Toronto Argonauts. Even though the cost of financing such facilities and their economic impacts has shown a wane in public support in recent times, it is still a central aspect of developing a new stadium and needs to be addressed.

\subsection{Financial Cost to Redevelop Current Stadium on Site}

Currently, as represented in Figure 1, BMO Field is approximately a 21,600 seat stadium specifically configured to MLS soccer for Toronto FC with field dimensions of 115 by 74 yards (Toronto FC, 2014). Concurrently, both the field size and seating capacity of the stadium are ill suited to host CFL football. Both would need to be addressed if the Argonauts were to move their home games to this facility on a full-time basis. The operator of the faculty, MLSE, devised an in-depth plan in late 2013 to address the potential for the team to play at this facility once their commitment to the Rogers Centre ends in 2018. City of Toronto officials voted on this proposed plan in April 2014, passing it in favour. 


\section{Figure 1: BMO Field, Exhibition Place, Toronto, Ontario}

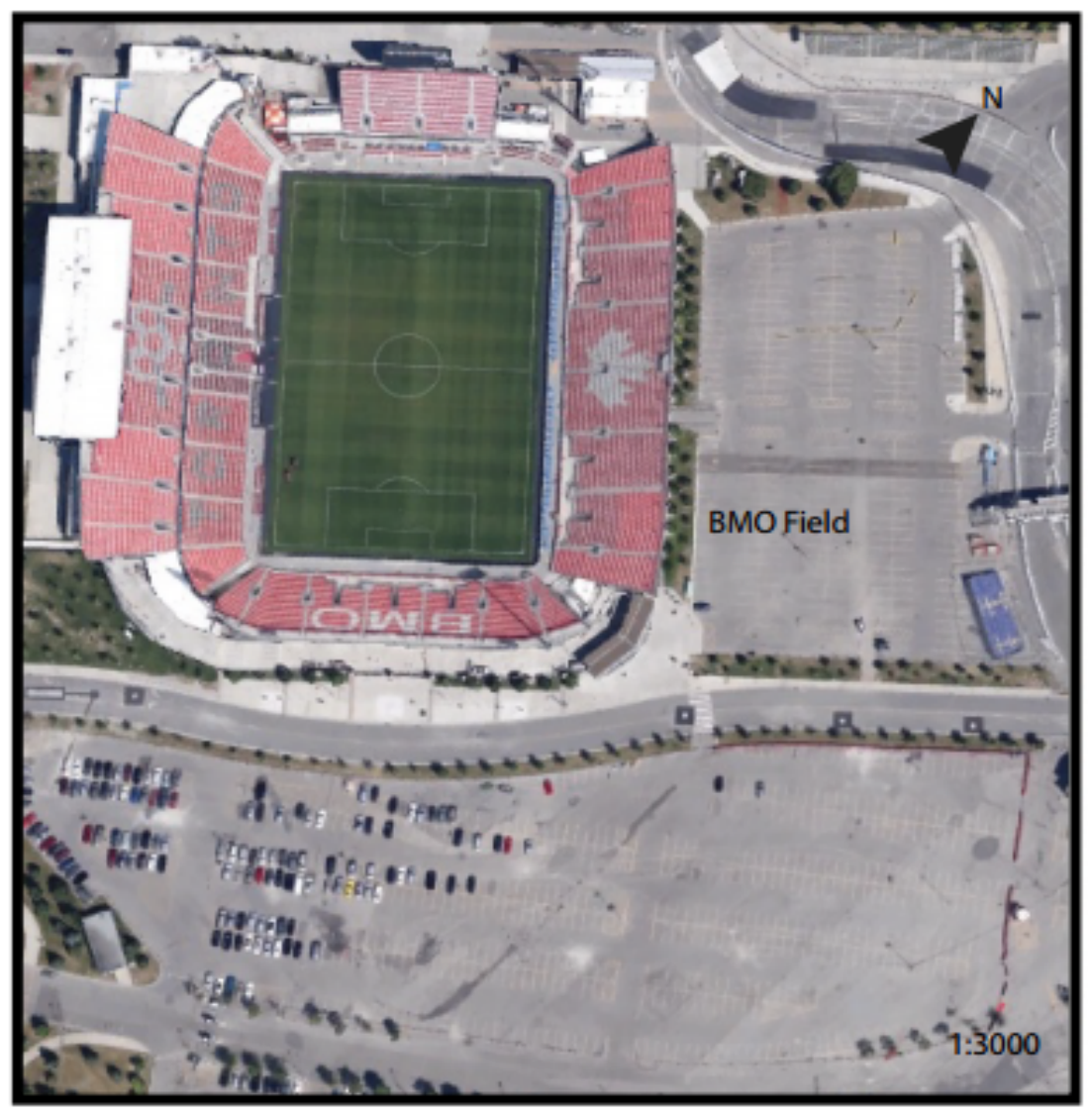

(Google Earth, 2015a)

Officially, in late 2013 MLSE revealed the full details of its two-phased renovation plan worth $\$ 105$ million (Stinson, 2014a), with the possibility of becoming a three-phased \$120-million renovation plan, for BMO Field (Rubin, 2014). In total the proposal would see MLSE contributing \$95 million toward the expansion, the City of Toronto taxpayers contributing \$10 million, and anticipates $\$ 10$ million in funding from both the Federal and Provincial Governments (Shum, 2014).

The first phase will be to add a second level to the east stand. This addition would raise capacity by 8400 seats or from 21,600 to approximately 30,000 (Hadden, 2014). There would be better amenities at the facility with new executive suites, private clubs, a wrap-around concourse and a new high definition video board. The cost of this initial 
phase is estimated to be $\$ 65$ million and will be complete by May 2015 in time for the Pan-Am Games (Hadden, 2014). The second phase is worth $\$ 40$ million and would see a roof installed above the facility with new lighting and sound system to be installed. Construction of this phase is expected to be complete by May 2016 (Toronto FC, 2014).

However, phase three is the big question mark of this proposal and whether it will actually be followed through with or not. Once an integral part of the renovation, this phase was to be the one that converts BMO Field into a stadium that, that would enable BMO Field to accommodate a CFL field by May 2017 (Toronto FC, 2014). Public funding to cover the third phase continues to be difficult to acquire, as the Federal Government remains consistent in saying it does not pay for sports venues (Hadden, 2014) and refuses to provide the $\$ 10$ million requested from MLSE. Whereas, the Provincial Government is still considering the request for it put $\$ 10$ million into BMO Field. There are also concerns with the third phase witnessed from a difference in opinions between City of Toronto officials both for against the allocation of more public funds to this stadium because it was already built on a significant amount of public funding (Hadden, 2014).

While in its current state, illustrated in Figure 2, Varsity Centre has a seating capacity of 5,000 and field dimensions of 130 by 65 yards, CFL regulation sized, for the University of Toronto's Varsity Blues football team (Rush, 2014). The Argonauts have also now returned to the stadium, successfully hosting 2013 and 2014 preseason games at their former home. This being said, the stadium is not adequately setup to host nine regular season home games due to the seating restraints and there are currently no plans for completing renovations to do so. This essentially forfeits an actual redevelopment 
cost assessment of Varsity Centre and what funds would be needed to complete such a project, severely challenging the claim for Varsity Centre to be compared. Therefore, an adequate and theoretical prediction to complete a redevelopment cost evaluation would need to be used in place of actuality. This would be a difficult preposition to make, however, there has been an example of precedence set in a similar situation with a CFL team successfully moving from an ill suited stadium to a smaller university one with historical ties.

Figure 2: Varsity Centre, University of Toronto, Toronto, Ontario

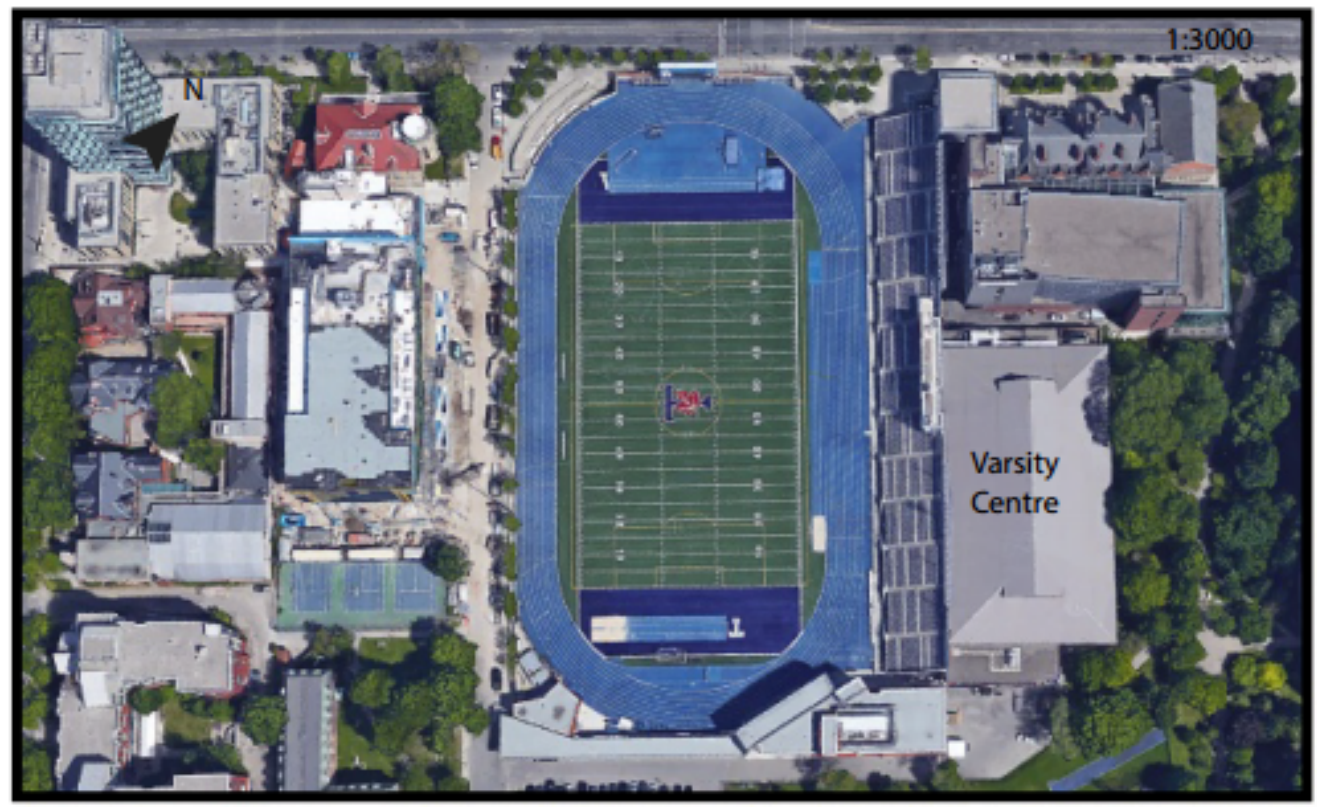

(Google Earth, 2015b)

The Montreal Alouettes franchise was playing their regular season home games at Olympic Stadium during the 1997 season, but attendance in the large stadium was very poor. This left the future of the franchise was in doubt. However, a chance occurrence of concert at Olympic Stadium conflicted with an unexpected home playoff game and the team moved the game to Molson Stadium, now Percival Molson Memorial Stadium on McGill University's campus to a massive success. This culminated with the ream 
relocating on a fulltime basis to this stadium in 1998 (Ferland, 2010).

The Toronto Argonauts situation is eerily similar, as the Toronto Argonauts have scheduled pre-seasons game at Varsity Centre, first occurring due to a conflict with the Rogers Centre primary tenant, Toronto Blue Jays schedule. At the time of the Alouettes relocation in 1998, the Percival Molson Memorial Stadium's capacity was 20,200 and an expansion completed prior to the 2010 season brought the current capacity to 25,000 (Ferland, 2010). This case proves to be an ideal size, as it would allow for a suitable and intimate seating capacity at Varsity Centre, slightly below the proposed 30,000 at BMO Field. The difference coming from a seating capacity that only holds 5,000 at the current stadium. It is similar enough to use the Percival Molson Memorial Stadium renovation model to theoretically predict a cost to renovations that could occur over time to see history repeat itself.

The renovation, completed in 2010, to Percival Molson Memorial Stadium increased its seating capacity to approximately 25,000 that cost $\$ 29.4$ million (CBC News, 2009). The renovation plan saw the demolition of the second tier and construction of a brand second tier of seating to the southern portion of the stadium, which added the majority of the 3,800 new seats. A new section was also added to the northeast portion of the stadium, and 19 new private suites were constructed. The cost of the renovations were shared by the Montreal Alouettes owner Robert Wetenhall who contributed $\$ 6$ million, the Quebec Provincial Government provided \$19.3 million, and \$4 million was provided from the City of Montreal (CBC News, 2009).

To complete a potential renovation, the Argonauts franchise would be looking to have a stadium that could support 25,000 fans. This would increase in capacity of 20,000 
from the 5,000 currently at Varsity Centre as the team needs to be able to host at least 21,000 fans to cover team costs as mentioned earlier. This is a much larger increase in seating capacity than what occurred at Percival Molson Memorial Stadium, though it needs to be taken into consideration that there were the demolitions of sections of this stadium before rebuilding. For the Argonauts, there is much more opportunity to build brand new stands and less demolition that would lower costs. Realistically, to see an increase in 20,000 seats built, the stadium would need to add a second tier to the eastern stands and completely build a stands to the western side of the playing field to the identical proportions. This new western tier could most feasibly house private suites, which have become a standard for newer stadiums or renovations.

The cost to do so could also be approximated by using numbers from the BMO Field renovation. During the first phase of renovation at BMO Field a second level will be added to the east stand, raising capacity by 8400 along with newer amenities that include new executive suites, private clubs, a wrap-around concourse and a new high definition video board for a cost of $\$ 65$ million (Hadden, 2014). To add a second tier to the eastern stands at Varsity Centre would give a seating capacity of approximately 10,000. There would also be the addition of a brand new western stands of comparable size with private suites that would be slightly larger and feasibly seat 14,000 . This would bring the capacity of Varsity Centre to that of a comfortable 24,000. Using the renovation methods and costs of both Percival Molson Memorial Stadium and BMO Field to approximate Varsity Centre's renovation would be adequate to fall somewhere between the two. Larger in scale than Percival Molson Memorial Stadium, but less intricate renovations than BMO Field though similar cost structuring would incur due to both 
stadium renovations taking place within the Downtown Toronto. Varsity Centre could then be estimated to cost approximately $\$ 40-45$ million to renovate adequately for the team. With money coming from a similar breakdown between the MSLE funding proposal and the Percival Molson Memorial Stadium funding with minor adjustments. This would see a proposed $\$ 15$ million from the Ontario Provincial Government, $\$ 10$ million from the City of Toronto, $\$ 10$ million from the University of Toronto, and $\$ 10$ million from the Toronto Argonauts.

Table 1 on the following page provides a summarizing breakdown of the characteristics and costs that need to be taken into consideration when determining adequate redevelopment between both stadium sites to allow them to host the Toronto Argonauts.

Table 1: Comparison of Sites and Redevelopment Characteristics

\begin{tabular}{|c|c|c|}
\hline Characteristics & BMO Field & Varsity Centre \\
\hline Current Stadium Seating & 21,500 & 5,000 \\
\hline $\begin{array}{l}\text { Required Amount of } \\
\text { Seating for CFL }\end{array}$ & \multicolumn{2}{|c|}{$22,000-25,000$} \\
\hline $\begin{array}{l}\text { Amount of Seating to be } \\
\text { Added to Stadium }\end{array}$ & 8,400 & 20,000 \\
\hline $\begin{array}{l}\text { Seating Number after } \\
\text { Redevelopment }\end{array}$ & 30,000 & 25,000 \\
\hline $\begin{array}{l}\text { Current Field Dimensions } \\
\text { (Yards) }\end{array}$ & $115 \times 74$ & $130 \times 65$ \\
\hline $\begin{array}{l}\text { Required Field Dimensions } \\
\text { for CFL (Yards) }\end{array}$ & \multicolumn{2}{|c|}{$130 \times 65$} \\
\hline $\begin{array}{l}\text { Changes needed to be made } \\
\text { to Field Size }\end{array}$ & Yes & No \\
\hline $\begin{array}{l}\text { Redevelopment Costs } \\
\text { (Millions) }\end{array}$ & $\$ 90-120$ & $\$ 40-45$ \\
\hline Proposed Funding Sources & $\begin{array}{c}\text { MLSE, City of Toronto, } \\
\text { Provincial and Federal } \\
\text { Governments }\end{array}$ & $\begin{array}{l}\text { University of Toronto, } \\
\text { Toronto Argonauts, City of } \\
\text { Toronto, Provincial } \\
\text { Government }\end{array}$ \\
\hline $\begin{array}{l}\text { Assurance Stadium could } \\
\text { Host CFL games after } \\
\text { Redevelopment }\end{array}$ & No & Yes \\
\hline
\end{tabular}




\subsection{Site Location Evaluation}

The following section presents a comparison of BMO Field and Varsity Centre based on the site location of each stadium. The objective of this exploration is to determine how each stadium's location acts to proximity to city centre and its proximity to client base within the city. As reiterated from before, locating the stadium in downtown or city centre locales allows sports facilities to create a sense of place upon the urban landscape for local residents.

\subsection{Site Proximity to City Centre}

Determining the proximity of each sports facility to Downtown Toronto or the city centre, is the primary central financial business district of the city is ideal to determine their practicality. This region of the city is bounded by Bloor Street to the north, Lake Ontario to the south, the Don River to the east, and Bathurst Street to the west and can be argued that is the most influential of the city. The area is made up of the city's largest concentration of skyscrapers and businesses, municipal government buildings, CN Tower, Union Station, and the Rogers Centre (where the team is currently housed). As this is the heart of the city, at times the Argonauts can be a forgotten commodity with such a concentration of activities within this area. Due to this a move from this highly competitive space would be beneficial, but in keeping the team near to the other draws is ideal, allowing the team to be more recognizable, while still offering the close proximity to the city's core. Both stadiums fall adjacent to the city centre, in appealing locales that are home to young professionals. More enticingly, these structures are places that would make the team more prominent within the area, giving the team a better chance to be a bigger draw. 
Shown in Figure 3, BMO Field is situated near the waterfront of Lake Ontario, at 170 Princes' Boulevard, approximately 4.5 kilometres west of the downtown central financial business district, the CN Tower and Toronto Union Station (Google Maps, 2015a). The stadium lies on the grounds of Toronto Exhibition Place and is bordered by the Gardiner Expressway and the Liberty Village neighbourhood to the north. The Exhibition covers 192 acres of land primarily used for entertainment with landmark buildings such as the Automotive Building, the Horticultural Building, the Better Living Centre and Ricoh Coliseum, Exhibition Place hosts more than 100 events each year (Toronto.com, n.d.) Major events include the Royal Agricultural Winter Fair, the National Home Show and the Honda Indy (Toronto.com, n.d.).

\section{Figure 3: Location of BMO Field and Distance from City Centre}

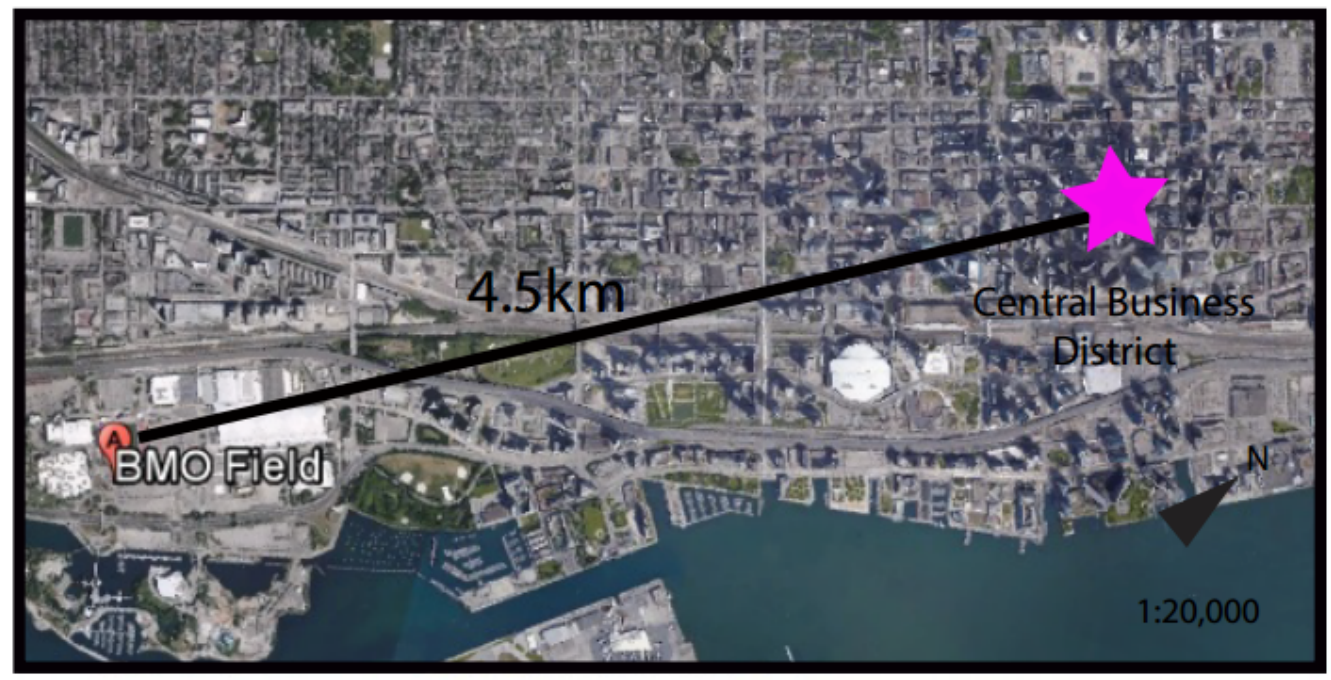

(Google Earth, 2015a)

While Varsity Centre, pictured in Figure 4, is located approximately 2.5 kilometres (Google Maps, 2015b) north of the he downtown central financial business district of the city, on Bloor Street West in the South Annex neighbourhood. The South Annex is a vibrant and colourful neighbourhood, much in part due to being located near 
to the University of Toronto (Toronto Neighbourhood Guide, n.d.b). The campus blends historical architecture and inviting green spaces as a backdrop to a truly remarkable community. Set in the centre of Toronto, it is a place with a vibrant academic life and countless co-curricular activities. Just beyond this area are the many neighbourhoods and industries that Toronto has to offer. The University also population mixes well with the young urban professionals who have helped the process revitalizing this historic Toronto neighbourhood.

Figure 4: Location of Varsity Centre and Distance from City Centre

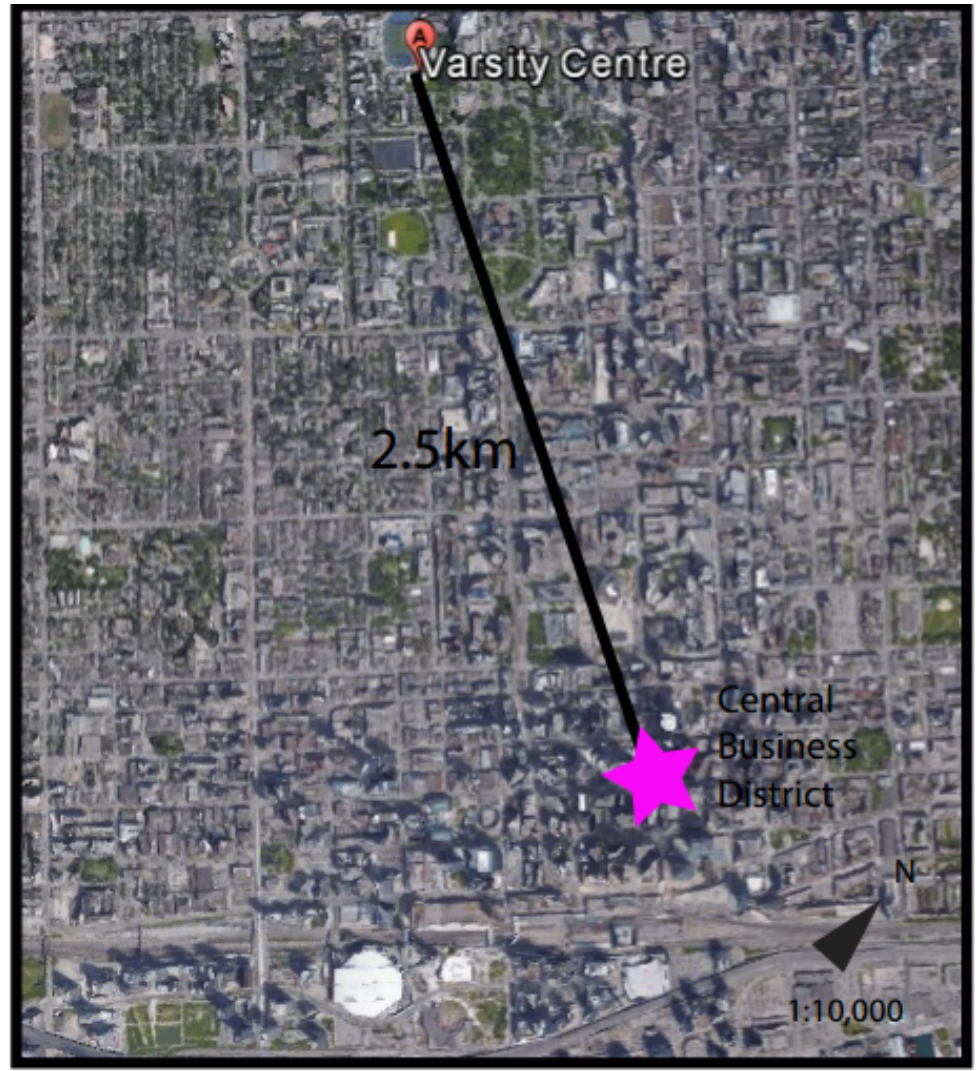

(Google Earth, 2015b)

\subsection{Site Proximity to Client Base}

Additionally, it is common to determine if the location of sports facility in question is in close proximity to potential client base to allow for ease of accessibility. 
Potential clientele will be looking to take some form of transportation to the game and with both stadiums located within downtown Toronto, each can continue to offer the access for the greatest number of spectators from surrounding city locales, as currently utilized by the Rogers Centre. That being said, the most preferred or favourable of catchment for potential patrons to the facility comes from a walkable catchment or pedestrian-shed (Calgary Regional Partnership, n.d.). This walking shed is most often found to be within a 5-10 minute walk from the destination in question and it is commonly known that most people are comfortable walking approximately 5-minutes (400 metres) regularly to their daily needs and, depending on the circumstance or the walking environment, may walk further to get to certain kinds of destinations reaching up to 10 -minutes (800 metres) or an extent at 15-minutes (1.2 kilometres) (Calgary Regional Partnership, n.d.). Knowing this logic will help to determine more certain the extent of each facility being in proximity to potential fans in their opposing locations.

Located on the waterfront of Lake Ontario isolates BMO Field from most neighbourhoods within the city, however it is nearest to Liberty Village. Liberty Village is a master-planned community, combining residential, commercial and retail uses. This neighbourhood is attracting to young professionals and businesses to the Liberty Village Business Area that desire to be in the central city (Toronto Neighbourhood Guide, n.d.a). Found within Table 2, are the population totals in close proximity to BMO Field, which is seen to have a the total 2014 population of approximately 41,100 (Simply Map 3.0, 2015a) within 1 kilometre of its location. This area of the city is also growing in population as there as been an increase from the 2011 population, which was approximately 36,800, an increase of 4000 (Simply Map 3.0, 2015a). There is an urban 
feel and a unique vibrancy to Liberty Village, which emanates from the Victorian industrial architecture that dominates the streetscape, which that has made it a very desirable locale within the city in recent years (Toronto Neighbourhood Guide, n.d.a). However, when observing the difference between the daytime population and the total population, the number decreases to 27,800 representative of in a $-68 \%$ change (Simply Map 3.0, 2015a). There is lesser chance of potential patrons to the stadium within a comfortable 15-minute walking distance. However, if the radius is increased to three kilometres the potential population increases to 152,900 and a daytime population increases to 428,500 or $280 \%$ (Simply Map 3.0, 2015a). This would allow a greater potential for those that could access the facility through some for of transportation.

Table 2: Representative Population in Relation to BMO Field Location

\begin{tabular}{|l|l|l|l|l|}
\hline \multicolumn{5}{|c|}{ BMO Field Location } \\
\hline & $\begin{array}{l}\text { Total } \\
\text { Population } \\
2011\end{array}$ & $\begin{array}{l}\text { Total } \\
\text { Population } \\
2014\end{array}$ & $\begin{array}{l}\text { Daytime } \\
\text { Population } \\
(2014)\end{array}$ & $\begin{array}{l}\text { Percentage } \\
\text { Change in } \\
\text { Daytime } \\
\text { Population } \\
(2014)\end{array}$ \\
\hline $\begin{array}{l}1 \mathrm{~km} \\
\text { Radius }\end{array}$ & 36,806 & 41,122 & 27,861 & $-68 \%$ \\
\hline $\begin{array}{l}3 \mathrm{~km} \\
\text { Radius }\end{array}$ & 137,931 & 152,949 & 428,546 & $280 \%$ \\
\hline
\end{tabular}

(Simply Map, 2015a)

Conversely, due to Varsity Centre being located closer to the city centre on Bloor Street West, it falls in much closer proximity to an abundance of neighbourhoods. Such neighbourhoods include the Annex, Yorkville, Kensington Market, and the Bay Street Corridor and these are some of the cities more dynamic and heterogeneous 
neighbourhoods that include young successful professionals, prominent artists, University of Toronto students and faculty, and people from all walks of life. There are also a number of businesses found within these Business Areas including hotels, theatres, restaurants, and prominent shopping districts. This has allowed the area to become very popular among for tourists with its many amenities and access to many potential patrons. Table 3 demonstrates that the total 2014 population within one kilometre of this vicinity is approximately 56,900 (Simply Map 3.0, 2015b). This area is also an ideal location because the population increased from 51,000 or by 6000 between 2011 and 2014 (simply Map 3.0, 2015b). The daytime population of the area also increases to approximately 107,200 , a $188 \%$ change in population, which demonstrates the amplified access to additional populations passing through the area or within a 15 -minute walk (Simply Map 3.0, 2015b). Opening up the potential radius to three kilometres, the total population increases to approximately 274,100 and a daytime population of 680,700 or an increase of $248 \%$ in the population within a short transport to the facility (Simply Map $3.0,2015 b)$.

Table 3: Representative Population in Relation to Varsity Centre Location

\begin{tabular}{|l|l|l|l|l|}
\hline \multicolumn{5}{|c|}{ Varsity Centre Location } \\
\hline & $\begin{array}{l}\text { Total } \\
\text { Population } \\
2011\end{array}$ & $\begin{array}{l}\text { Total } \\
\text { Population } \\
2014\end{array}$ & $\begin{array}{l}\text { Daytime } \\
\text { Population } \\
(2014)\end{array}$ & $\begin{array}{l}\text { Percentage } \\
\text { Change in } \\
\text { Daytime } \\
\text { Population } \\
(2014)\end{array}$ \\
\hline $\begin{array}{l}1 \mathrm{~km} \\
\text { Radius }\end{array}$ & 50,971 & 56,937 & 107,255 & $188 \%$ \\
\hline $\begin{array}{l}3 \mathrm{~km} \\
\text { Radius }\end{array}$ & 251,971 & 274,174 & 680,742 & $248 \%$ \\
\hline
\end{tabular}

(Simply Map 3.0, 2015b) 


\subsection{Accessibility Evaluation}

The following section will provide an evaluation of the accessibility of each stadium's location. This evaluation is imperative because the primary modes of daily transportation in society are through private vehicle, public transit, and walking. Therefore, each site will be further evaluated on vehicular access and parking requirements, access to public transit, and pedestrian accessibility to determine their viability.

\subsection{Vehicular Accessibility and Parking}

Located in Exhibition Place, BMO Field is adjacent to both a major expressway and arterial road in its proximity. More specifically, the stadium is bounded to the north, south, east, and west with access within minutes the Gardiner Expressway and Lake Shore Boulevard, which provide east-west access to a network of highways leading directly to and out of the downtown core (Toronto Neighbourhood Guide, n.d.b). The site is also positioned close to three local collector roads, Dufferin Street and Strachan Avenue running north-south and Princes' Boulevard running east-west. These would be the roads that vehicles would primarily use when leaving the stadium from one of the numerous parking lots, illustrated in Figure 5, containing 6,128 parking spaces, 1,300 of which are underground (Exhibition Place, n.d.). There are also other local streets that are accessible from a 15-minute walk or less under the Gardiner Expressway and through the closely located Exhibition Go Station to Atlantic Avenue, which runs north-south. Once on Atlantic avenue travelling north there are another five municipally owned, Toronto Parking Authority lots offering a further 710 parking spaces (Municipal Parking, n.d.a). 


\section{Figure 5: Potential Onsite Parking Surrounding BMO Field}

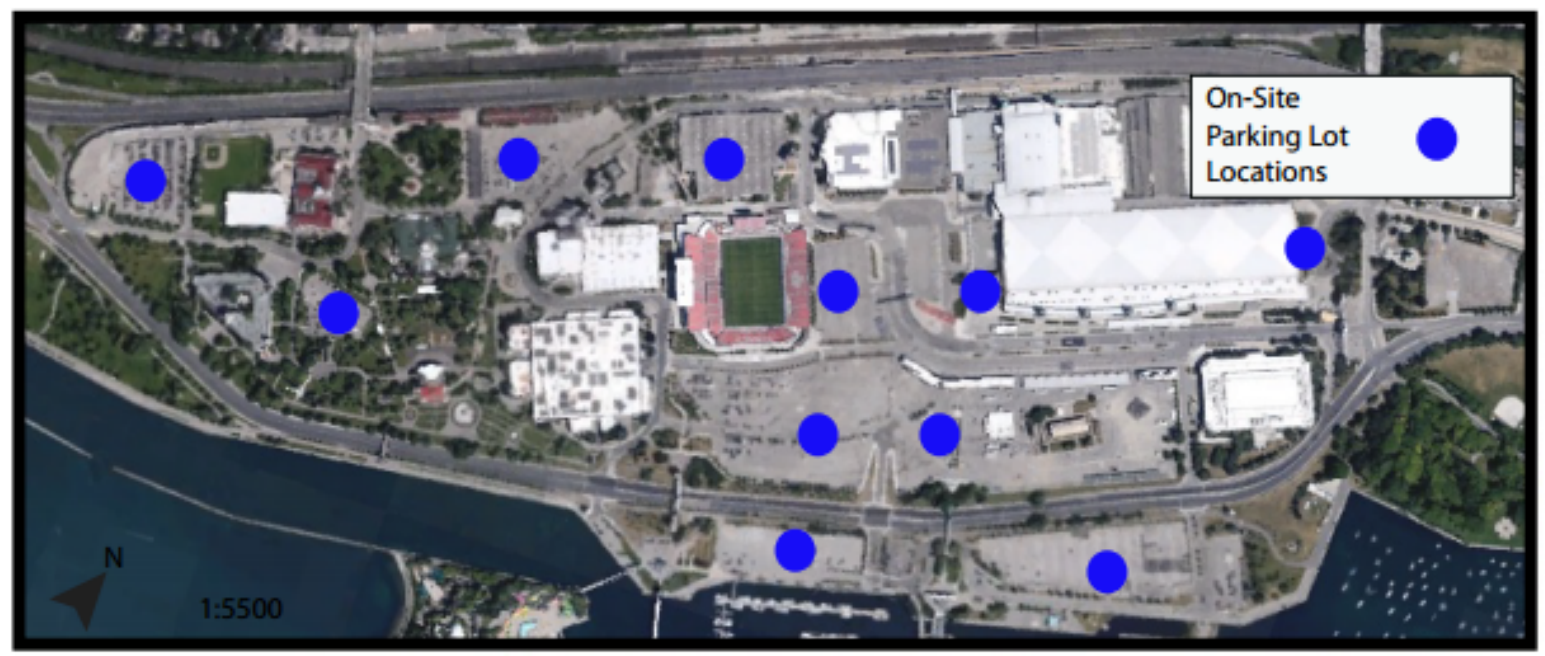

(Google Earth, 2015a)

While located on the University of Toronto's campus, Varsity Centre is

surrounded by an abundance of local collector roads to the nearby neighbourhoods and within close proximity of Toronto's business and entertainment districts. Roads running east-west include Bloor Street and Dupont Street to the north, College Street, Harbord Street, Hoskin Avenue, and Dundas Street to the south. Roads running north-south include St. George Street to the east and Bedford Road, Avenue Road, Bay Street and Yonge Street to the west. There are also two arterial roads Spadina Avenue and Queen's Park and the local collector road, Bay Street, that run north-south. The routes are approximately 25-30 minutes from the Gardiner Expressway that provides access to the network of highways leading directly to and out of the downtown core (Toronto Neighbourhood Guide, n.d.c). It must also be mentioned that although Bloor Street is not a major arterial road, it does provide the quickest thoroughfare east to the major expressway, the Don Valley Parkway, in approximately 12-15 minutes (Google Maps, 2015). In terms of parking, Figure 6 displays the locations of the approximately 23 parking lots and approximately 1500 spaces on the University of Toronto campus 
(University of Toronto, n.d.b). To go along with the parking on the University of Toronto campus, there are another 15 municipally owned, Toronto Parking Authority lots offering a further 2500 parking spaces within a 15-minute walk of Varsity Centre (Municipal Parking, n.d.b).

\section{Figure 6: Potential Onsite Parking Surrounding Varsity Centre}

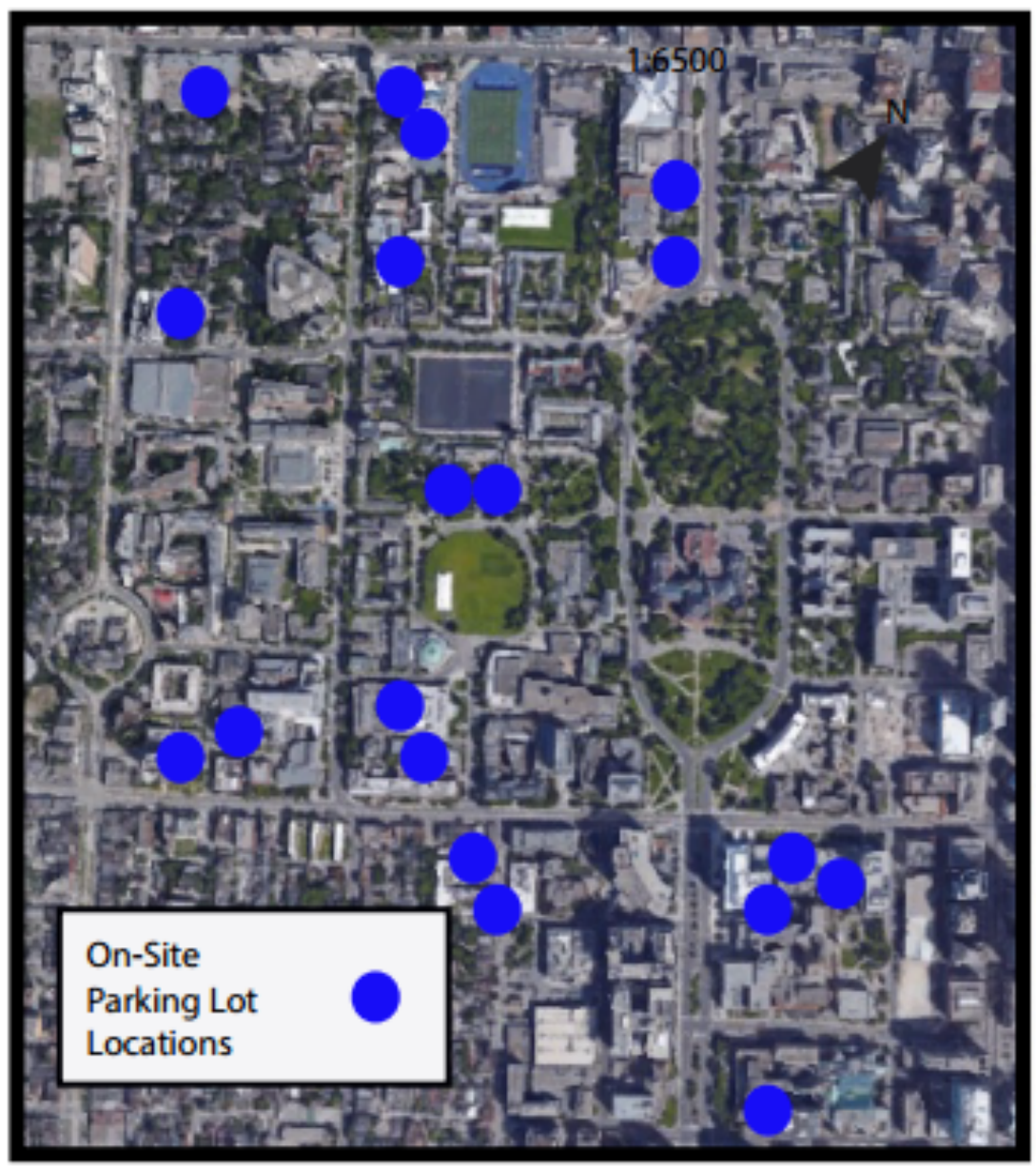

(Google Earth, 2015b)

\subsection{Public Transit Accessibility}

BMO Field is serviced by the Toronto Transit Commission (TTC) by the 29 Dufferin Bus, 511 Bathurst Streetcar, and the 509 Harbourfront Streetcar that provide easy access to and from the site to the downtown financial central business district and other locales. These two streetcars stop at Exhibition Place, at Strachan Avenue, and 
adjacent to the Horse Palace and the Government of Ontario (GO) Transit Exhibition Station (Exhibition Place, n.d.). Go Transit's Exhibition Station, is approximately a 5minute walk from BMO Field and is accessed by either the Lakeshore East or West lines running every 30-minutes, 15-minutes during rush hour, east-west to Union Station and the surrounding neighbourhoods and municipalities along the waterfront (Toronto Neighbourhood Guide, n.d.a).

Comparatively, Varsity Centre is extremely well served by public transit, starting with its two nearby streetcar lines. The 510 Spadina, runs north-south along Spadina from the Spadina subway station to the west of the stadium. There is also the 506 Carleton Streetcar, that runs east-west along College Street though Queen's Park subway station south of the stadium (University of Toronto, n.d.a). Both of these stations are among the 10 subway stations within a 15 -minute walk of the stadium. However, the three subway stations at Spadina and St. George on the Bloor-Danforth line running east-west, and at Museum and St. George, on the Yonge-University-Spadina line running north-south, provide direct access to Varsity Centre within a 2-7 minute walk (Toronto Neighbourhood Guide, n.d.c). With trains running every 3-minutes in service times, this provides the greatest access to surrounding neighbourhoods and the downtown core. Once on the Yonge Spadina Line departing south, it will take approximately 15-minutes to reach Union Station, the central mobility hub. At Union Station access to Go Transit trains and buses provide access to outer municipalities.

\subsection{Pedestrian Accessibility}

Upon arriving or departing from BMO Field, a swath of parking lots and big box buildings to navigate through in the direct vicinity greets pedestrians. Once through 
heading north on Nova Scotia Avenue north towards Exhibition Go Station, where there is a mobility hub. This location provides pedestrian access to alternative modes of transportation services through hosting a City of Toronto bike-share hub and bicycle parking (Exhibition Place, n.d.; Go Transit, n.d.). However, once through Exhibition GO Station, continuing north towards Liberty Village along Atlantic Avenue the pedestrian infrastructure becomes insufficient and broken between the connection of Atlantic Avenue and the Go Station. The other thoroughfare comes from heading east along Princes' Boulevard to Strachan Avenue, but that route takes approximately 15-minutes, elapsing the ideal walking catchment as represented in Figure 7. The final option is to walk west along Princes' Boulevard to Dufferin Street, a 10-minute walk on the brink of the ideal pedestrian shed. Being the closest direct thoroughfare for pedestrians, this infrastructure between the Go Station and Atlantic Avenue could be greatly improved for more connection to the neighbourhood from BMO Field. 


\section{Figure 7: Representative 15-Minute Walk Radius Surrounding BMO Field}

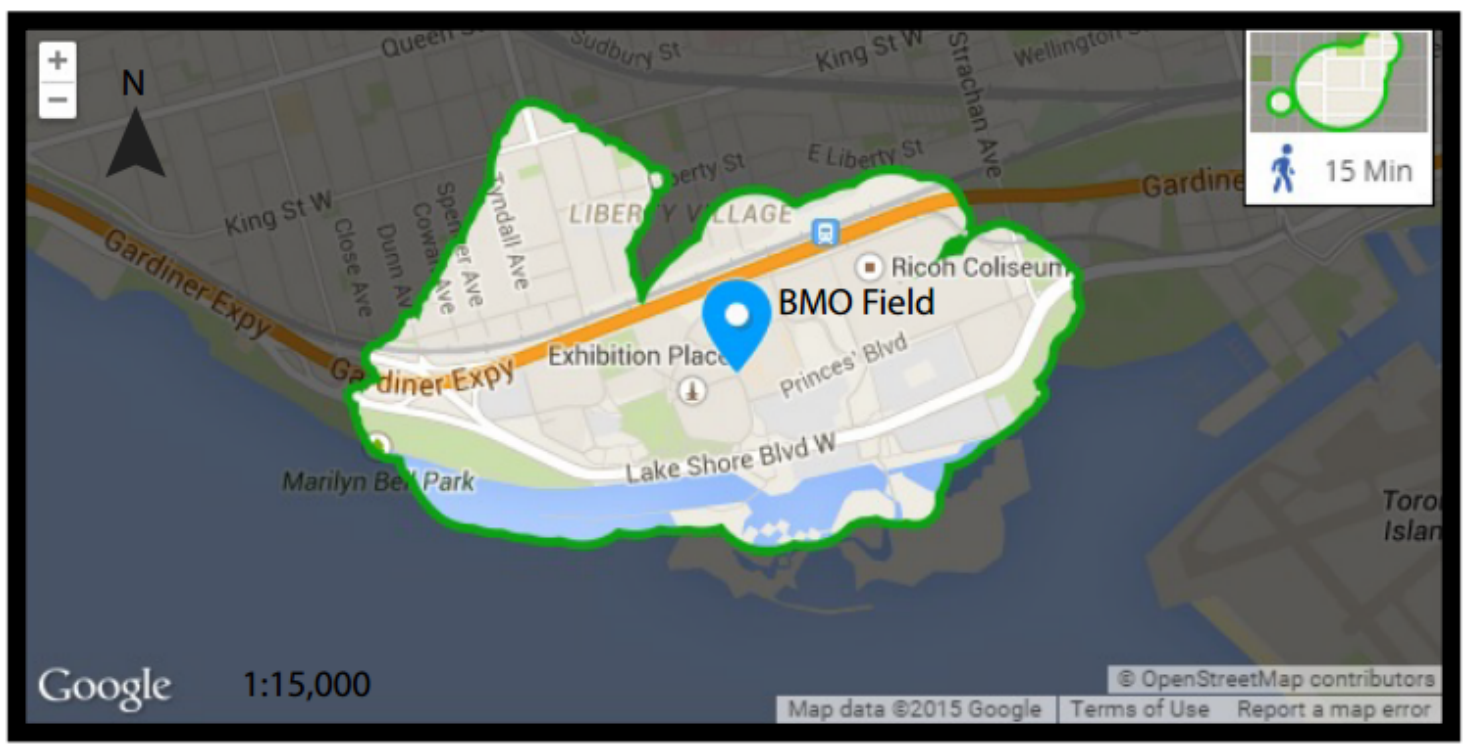

(Walk Score, 2015a)

Whereas, throughout the University of Toronto Community, pedestrian and alternative means of transportation are encouraged. Bike lanes have previously been installed on St. George Street, Harbord Street, Hoskin Avenue, College Street and Wellesley Street to provide for a great means of thoroughfare through the community. This connectivity is emphasized as Varsity Centre is also in close proximity to approximately 91 locations with bike racks up to 100 post and ring stands at University of Toronto campus (University of Toronto, n.d.). A partnership between the City of Toronto and university has seen bike lockers installed at two campus locations being (71 Prince Arthur Avenue and 371 Bloor Street West) that are within a 15-minute walk of the stadium (University of Toronto, n.d.). A 15-minute walking radius is clearly defined within Figure 8, with that many of these locations located within. The University of Toronto also encourages the calming automobile traffic, minimizing obstructions for pedestrians including people with disabilities, and providing coordinated high quality streetscape (City of Toronto, 2006). The Bloor Street connection immediate to Varsity 
Centre location includes wider sidewalks, appropriate street lighting and furniture, and buffered pedestrian areas that provide safety and comfort that joins the facility on the University of Toronto campus to the city.

Figure 8: Representative 15-Minute Walk Radius Surrounding Varsity Centre

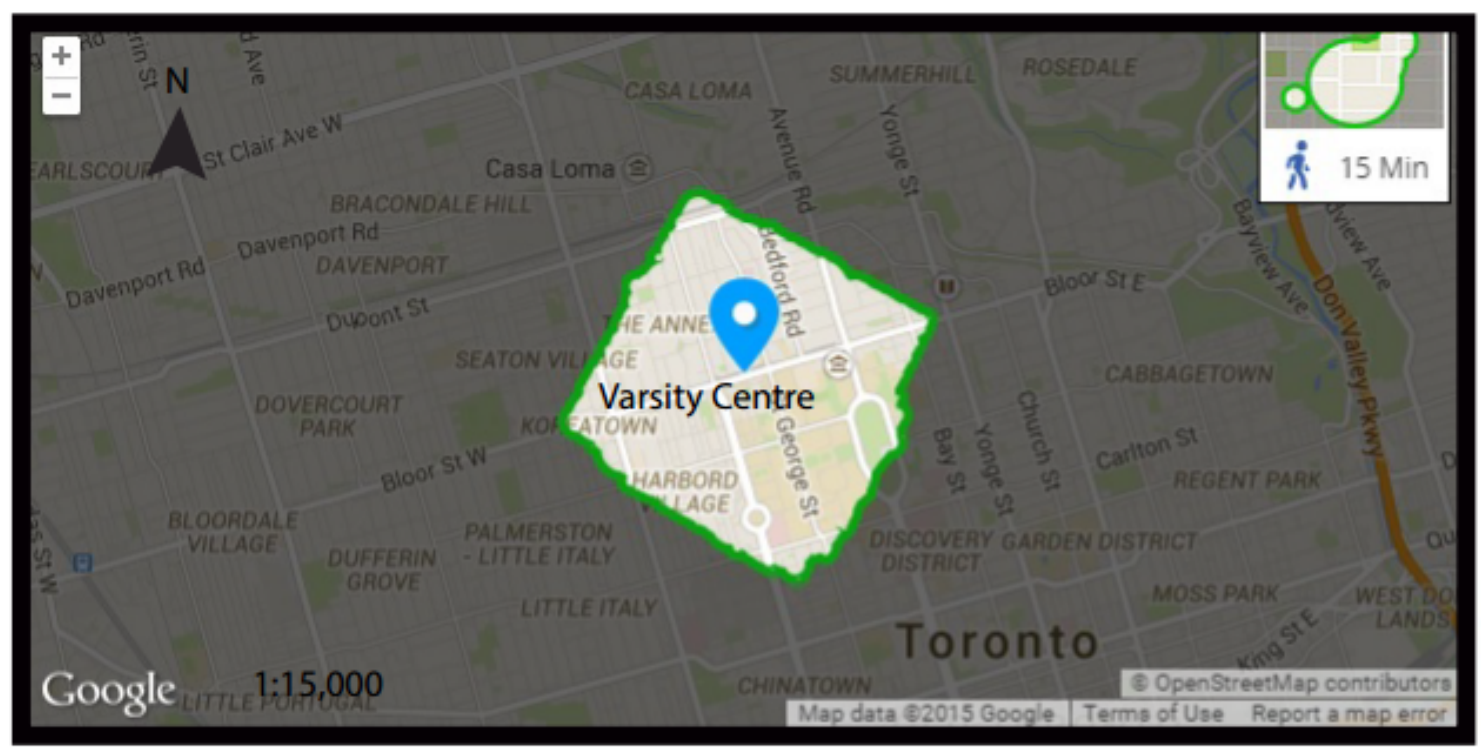

(Walk Score, 2015b) 


\subsection{Surrounding Land Use Evaluation}

As a professional sports stadium has the ability to bring a large number of patrons to a given area in a short amount of time, it is important to understand how a stadium's location and surrounding land uses can affect the overall experience for potential fans. Consequently, this final section focuses on an evaluation to compare BMO Field and Varsity Centre according to how each stadium would potentially function in their surrounding neighbourhoods if the Toronto Argonauts were to play their homes games at the given site. The evaluation was completed through assessing each stadium's proximity to ancillary activities and its integration to the surrounding area.

\subsection{Site Proximity to Supplementary Activities}

BMO Field is located in an identified regeneration centre within the City of Toronto, currently used heavily for entertainment, with other attractions as the Ricoh Coliseum, Band Shell Park, and Direct Energy Centre being large-scale facilities that draw visitors to the vicinity. However, none of these aforementioned sites would be considered ancillary because a potential patron would not typically visit one before or after a three hour Toronto Argonauts game. Yet, within a 15-minute walk there are approximately 130-140 supporting uses, most notably located to the north of the stadium in Liberty Village (Liberty Village BIA, n.d.). Liberty Village is an employment centre and contains many businesses pertaining to food, entertainment, services, and shopping that would bring visitors and professionals to the adjacent area on a regular basis that would use these supporting uses before and after Argonaut games. As a result of the restricted supporting uses at the extent of a comfortable walking catchment, represented in Figure 9, patrons of the stadium will be pressured and inconvenienced to extend their 
experience in the surrounding area before and after games. With a lack of supporting uses in the immediate vicinity of the stadium, along with the access of parking and access to transit, and an identified regeneration area there is likely to be a duller urban environment with less street life. This will lead to less economic spillover over, as visitors to the stadium are more likely to attend a game and then immediately leave upon its completion.

Figure 9: Surrounding Land Use within a 15-Minute Walk Catchment of BMO Field

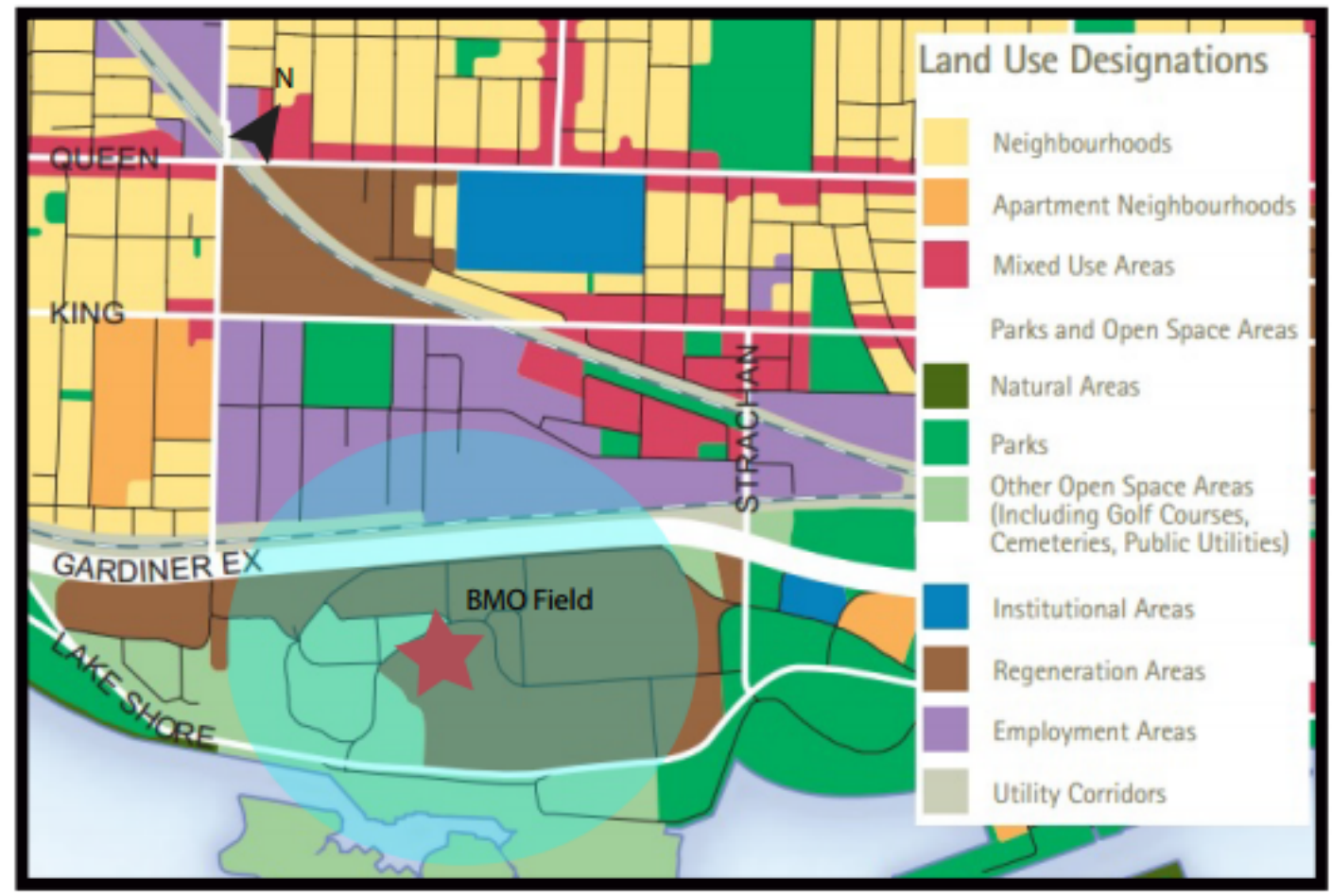

(City of Toronto, 2010)

Evidently different compared to that of BMO Field, Varsity Centre is located in a visitor oriented commercial and institutional area. As mentioned previously, visitors to the stadium will primarily use Bloor Street, Avenue Road, Spadina Avenue, St. George Street, Bay Street, Harbord Street, Hoskin Avenue, and Yonge Street. Traveling along these routes pedestrians could encounter any number of the five commercial districts, Bloor Annex, Bloor-Yorkville, Chinatown, Church-Wellesley, Kensington Market, and 
Downtown Yonge, with more than 4500 supporting uses within a 15-minute walk (City of Toronto, n.d.). These uses range from food, entertainment, services, and shopping and more than likely something to draw any type of patron imaginable, providing spectators with the greatest opportunity to spend money, and extend their overall experience before and after a Toronto Argonauts game in the surrounding neighbourhoods. With the copious amounts bars, restaurants, shops, and hotels it gives visitors opportunities to make an all day event of the game and truly embrace the experience within the 15-minute walking catchment provided in Figure 10. Not only should this add to the vitality of the stadium, but it could also help add to the economic activity and overall vibrancy of the urban environment in the area that the team would definitely benefit from. With the transportation accessibility there are many options to walk through one of these areas after parking or using public transit. 
Figure 10: Surrounding Land Use within a 15-Minute Walk Catchment of Varsity Centre

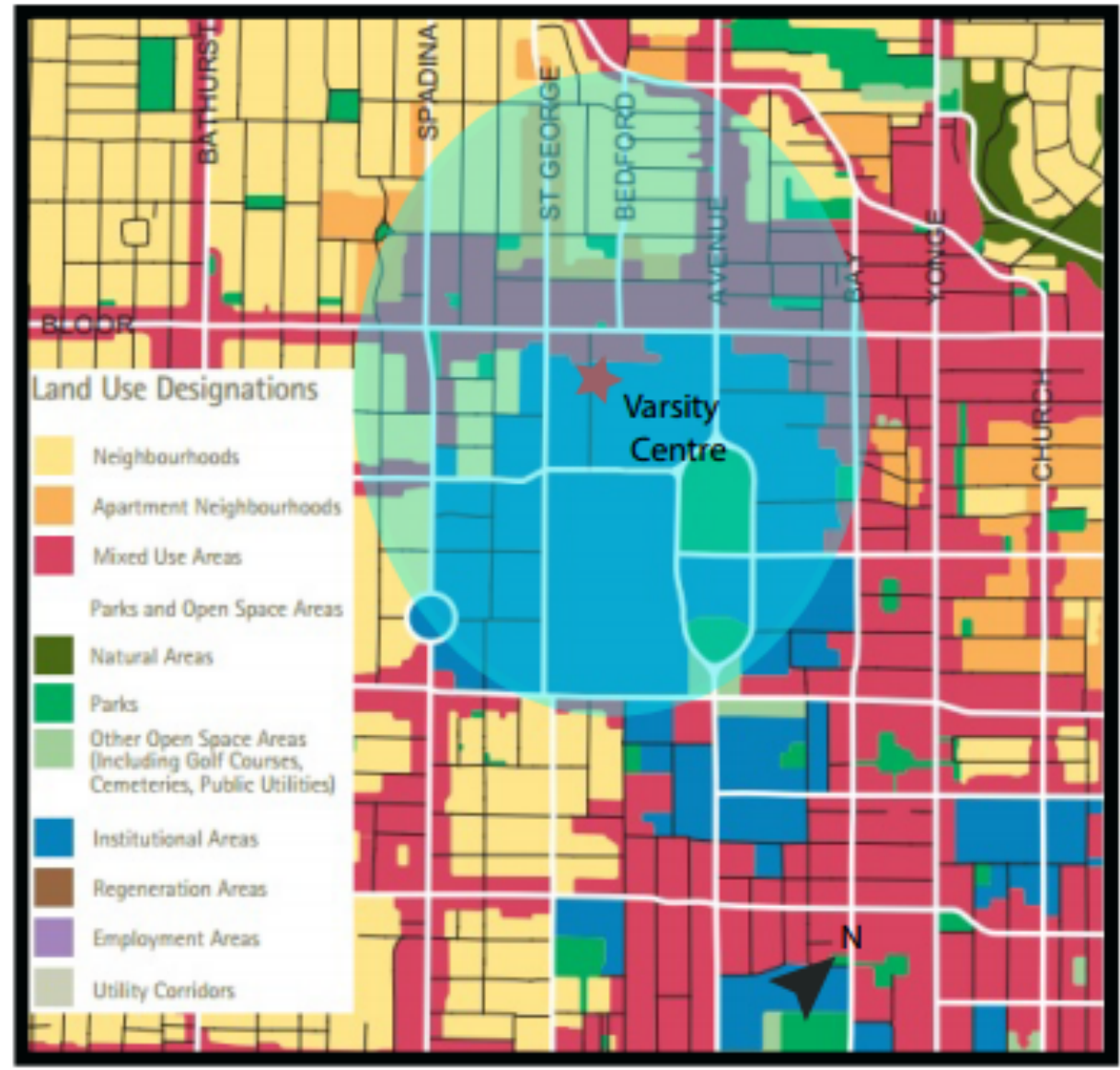

(City of Toronto, 2010)

\subsection{Site Integration into Surrounding Area}

With a larger and more diverse number of ancillary uses, can come more active and interesting urban streetscape that can add to the overall appeal of each patron's experience. With more streets and connectivity comes more choices and with more choices can lead to newly found experiences each time a potential client travels to and from a game. Urban Planners can use such techniques as a figure ground diagram to clearly illustrate the relationship between mass and void surrounding identified locales within he urban fabric of the city. A figure ground diagram represents the relationship between built and unbuilt space wherein white represents unbuilt space while black 
represents the built space.

Seen from Figure 11, the immediate vicinity that BMO Field is located within has sparsely built up urban environment. This is illustrated due to the expansive representation of white (negative) space, compared to black (positive) space within the area. BMO Field's location is illustrated in the diagram as the grey square. There is a noticeable lack of city blocks and intersection, which decreases the prospect for a visitor to experience a vibrant and diverse urban environment. A reduced representation of building mass to open space can allow buildings to feel disconnected from the urban fabric and can be illustrative of surface parking lots within the area. It also creates a lack of sense of place with no identity. There is also the fact that because of the immediate area being sparsely built, that there are only three options for pedestrian movement in or out of this area. This lack of choice can discourage pedestrians from wanting to travel to the Liberty Village neighbourhood to the north and the commercial locations that are at the outer limits of the 15-minute pedestrian shed. These commercial locations, themselves are then also limited being on the outer limits of the 1.2 kilometre, 15-minute walk distance and the lack of main thoroughfares may diminish the desirability for visitors to extend visits into the other nearby vicinities and find ancillary uses, which in turn are limited themselves in terms of opportunity. 
Figure 11: Illustration of the Built and Unbuilt Space Surrounding BMO Field

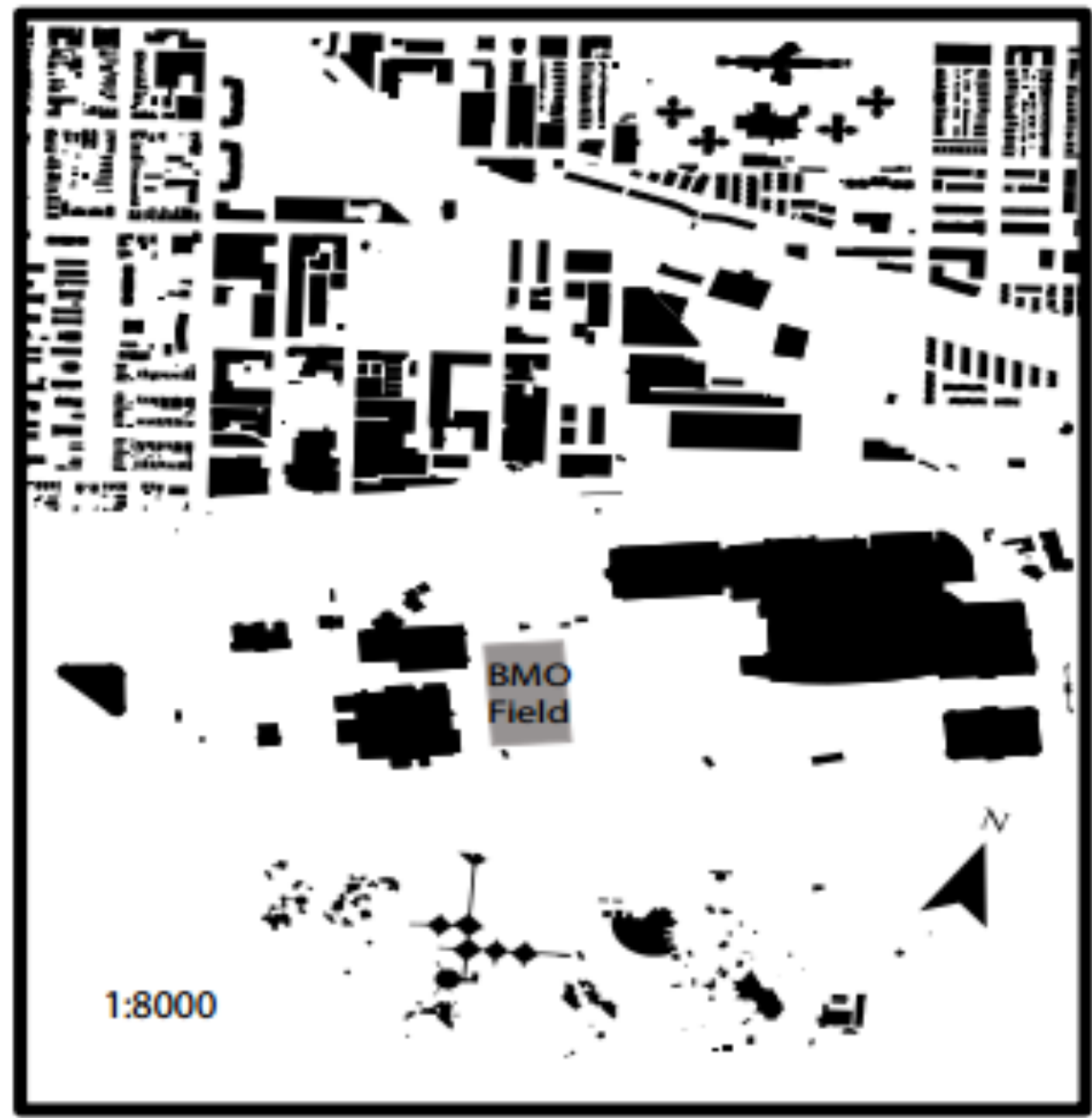

(City of Toronto, 2013)

Unmistakably, Figure 12 representing the space surrounding Varsity Centre demonstrates a more connected grid patterned area. Shown in black is the existing block pattern and the location of Varsity Centre is displayed as grey. Within 1.2 kilometres, 15minute walk of the stadium there are an abundance of blocks in numerous shapes and sizes with many intersections splitting them up. A greater representation of building mass to open space represents urban space with well-defined connective elements to link the area. This grid pattern encourages the movement of people in all directions and increases the likelihood of never experiencing the same trip twice. As a result, this closer knit built 
urban fabric generates diversity and can help to explain why there is such a great variety and number of ancillary uses in close proximity to Varsity Centre. This can enhance the experience of those fans that travel through the area and give the commercial areas a great accessibility to come into contact with those same visitors.

Figure 12: Illustration of the Built and Unbuilt Space Surrounding Varsity Centre

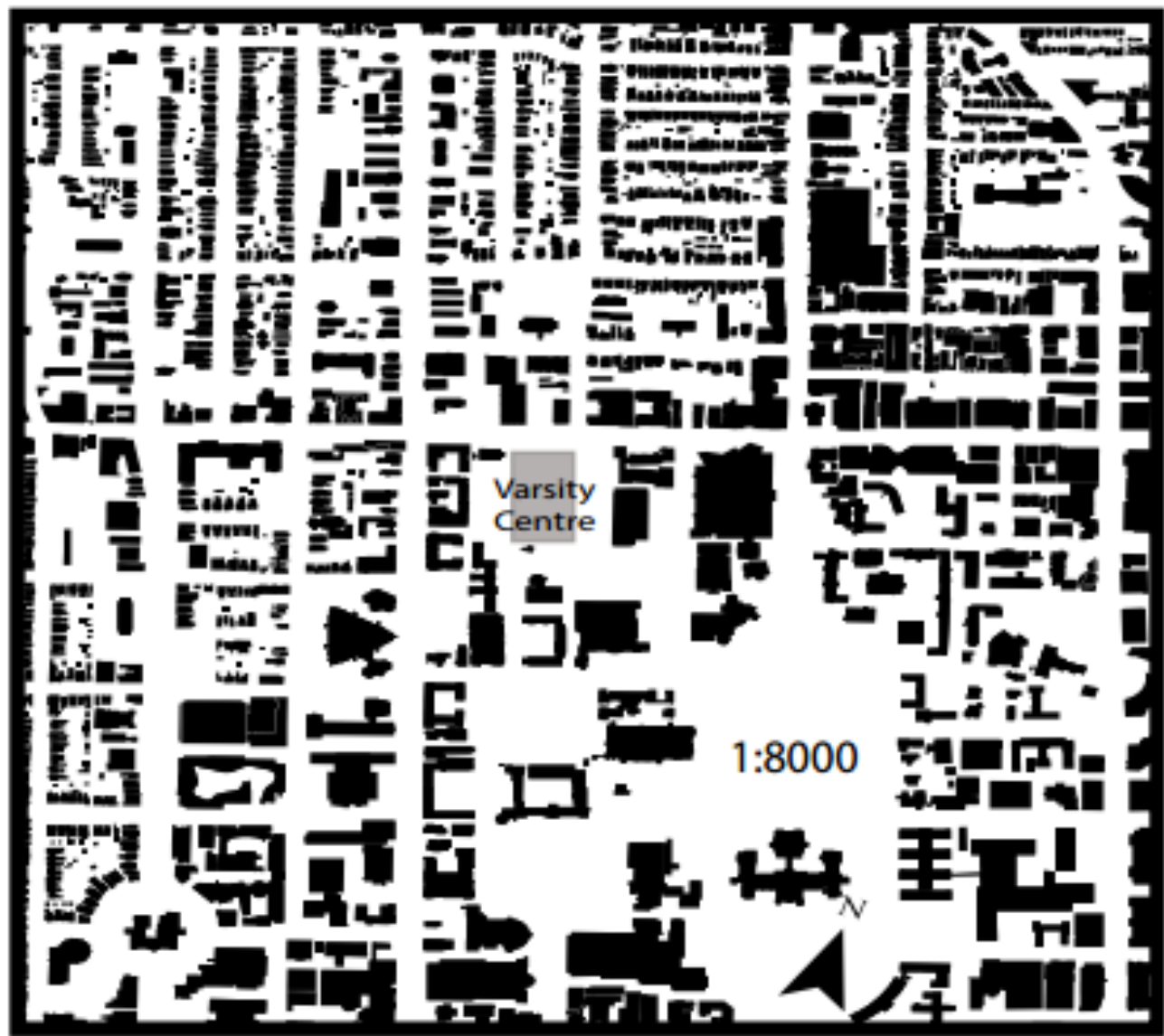

(City of Toronto, 2013) 


\subsection{Conclusions}

A comparison case study has been presented of the two stadiums, BMO Field and Varsity Centre located within the City of Toronto, to considered each as a possible new facility to host the Toronto Argonauts home games. While completing this comparison, it was important to acknowledge that through planning to move a professional sports team to a new stadium location within a city, the impending benefits and disadvantages from moving to each potential facility. However, the potential of either stadium to host the team differs due to their proposed redevelopment costs, location of the stadium's site, their accessibility linkages, and surrounding land uses make them unique in in their ability to host the Toronto Argonauts football team. Through the completion of this study, benefits and disadvantages have been determined for each stadium that allows for, solidified conclusions to be made. A further in-depth look will provide an isolated perspective of each stadium in its current location in downtown Toronto.

\subsection{Redevelopment Cost Conclusion}

When it comes to the proposed costs of redeveloping either facility to be able to adequately house the team, both face different challenges of fiscal concern. BMO Field's proposed cost to allow the facility to become the home stadium of the Toronto Argonauts is big question mark. The redevelopment cost of the first two initial phases is estimated to be approximately $\$ 105$ million, to be complete by May 2016 (Hadden, 2014). The question becomes apparent in the potential of the third phase to a three-phased proposal and whether it will actually be followed through with or not remains to be seen. Once an integral part of the renovation, upper level government funding to cover the third phase continues to be difficult to acquire, as the Federal Government remains consistent in 
saying it does not pay for sports venues (Hadden, 2014) and refuses to provide the $\$ 10$ million requested from MLSE. Whereas, the Provincial Government is still considering the request for it put $\$ 10$ million into BMO Field. With this third phase of development, it pushes the proposed project to $\$ 120$ million dollars.

Conversely, there has been no such proposal for the redevelopment of Varsity Centre to become the new home facility of the Toronto Argonauts. This essentially forfeits an actual cost evaluation of Varsity Centre and what funds would be needed to complete such a project, severely challenging the claim for Varsity Centre to be compared. However, there is an example of precedence set in a similar situation with a CFL team successfully moving from an ill suited stadium to a smaller university one with historical ties and could theoretically work in this situation. Using the case of Percival Molson Memorial Stadium the Varsity Centre could be estimated to be approximately \$40-45 million. With money coming from a similar breakdown between the two examples used with $\$ 15$ million from the Ontario Provincial Government, $\$ 10$ million from the City of Toronto, $\$ 10$ million from the University of Toronto, and $\$ 10$ million from the Toronto Argonauts.

Varsity Centre would be the most desirable option for the reasons of it being a cheaper alternative and that the sources of funding would be spread out more appropriately. There would no longer be any requirement for the Federal Government to contribute to the redevelopment project; the City of Toronto would be placing the same amount of monetary funds towards the project, and slightly more from the Provincial Government. To redevelop this stadium would become less intensive in terms of 
construction costs, due to less demolition, while the cost breakdown would be much more fitting and acceptable from all parties involved.

\subsection{Site Location Conclusion}

In terms of the Site Location assessment three measures were used to compare both facilities that included the proximity to city centre, the proximity to client base and site location within the community. The city centre of Toronto is the primary central financial business district, with the largest concentration of skyscrapers and businesses, municipal government buildings, extractions, and transportation hub of Union Station, which provides the locale with the greatest compatibility with the urban fabric of the city and its population.

BMO Field is located near the waterfront of Lake Ontario, approximately 4.5 kilometres west of the city centre within Exhibition Place, primarily used for entertainment throughout the year. Due to this location in a major entertainment district, there is expansive land needed for other buildings and parking, that can isolate such a facility from larger portions of the population or potential clientele within comfortable walking distance. BMO field's proximity to a potential client base or neighbourhood, is closest to Liberty Village. With a comfortable walking distance being stated earlier to be potentially 5-10 minutes for daily needs, with longer times given for circumstances such as football games once a week, a walking time of 15 -minutes is sufficient. To walk 15minutes is estimated to be about a distance of 1.2 kilometres and the 2014 population of the city that fell within a one kilometre walking distance from BMO Field was 41,100. The population of this area is growing as well as from 2011-2014 the population grew by 
4,000 , however there is a negative daytime population at $-68 \%$ during the day compared to those that live within the area.

While, Varsity Centre is located on Bloor Street and approximately just 2.5 kilometres north from the downtown central financial business district on the University of Toronto campus. The central location makes it easily accessible to the team's client base within a 15-minute pedestrian shed. Closely located are such neighbourhoods as the Annex, Yorkville, Kensington Market, and the Bay Street Corridor. These are some of the cities more dynamic and heterogeneous neighbourhoods that include young successful professionals, prominent artists, University of Toronto students and faculty, and people from all walks of life. The 2014 population within the city that falls a one kilometre, 15-minute walk from Varsity Centre was 56,900. The population growth within the area has also increased by approximately 6,000 between 2011-2014 and has a positive daytime change of $188 \%$ with more than 107,200 during the day.

Both sites are located outside the primary city centre financial district and have comparable 2014 population numbers, population growth, and tie in well with the dominant land uses of each location, however, that is where the similarities of the two facilities differ. Varsity Centre becomes the more strongly identified location upon a closer look. Being just 2.5 kilometres from the city centre, it is closer to a greater number of neighbourhoods, its population overall is greater, and it has a positive daytime population change. All these reasons make the site of Varsity Centre stronger than the site of BMO Field. 


\subsection{Accessibility Conclusion}

Through the completion of an accessibility evaluation, three conditions were used to compare the suitability of both facilities that included vehicular accessibility and parking, public transit, and pedestrian accessibility. Being that both facilities are located within the city centre of Toronto, these are three evaluations that pose as pressing challenges within a city when a Toronto Argonauts game was taking place. Making a comparison of this nature crucial in deciding upon a new locale.

With BMO Field located at Exhibition Place, it is incredibly user-friendly in terms of vehicular and parking, falling adjacent to a major expressway (Gardiner Expressway), an arterial road (Lake Shore Boulevard), local collector roads (Dufferin Street, Strachan Avenue, and Princes' Boulevard), and an abundance of on site and nearby parking facilities, approximately 6,800 within in a 15 -minute walk proximity. The facility is also provided with a moderate amount of nearby public transit options, being serviced by three TTC transit routes (29 Dufferin Bus, 511 Bathurst Streetcar, and 509 Harbourfront Streetcar) and the GO Transit Exhibition station train terminal directly at Exhibition Place. However, due to the abundance of options for vehicular accessibility and parking lots, the area's pedestrian accessibility is weakened. In terms of pedestrian accessibility, BMO Field has a bike share location at Exhibition GO station, but continuing by foot north towards Liberty Village along Atlantic Avenue the pedestrian infrastructure becomes insufficient and broken between the connection of Atlantic Avenue and the Go Station.

Contrary to BMO Field, Varsity Centre is located on the University of Toronto's campus. Varsity Centre is surrounded by an abundance of local collector roads to the 
nearby neighbourhoods and within close proximity of Toronto's business and entertainment districts. Having a more interior location within the city the site is isolated in terms of easy accessibility for vehicular traffic, being approximately a 25-30 minute drive to any major highways. However, there are an abundance of arterial and collector roadways nearby that run both east-west and north-south to pass vehicular traffic throughout the area. These include such roads as Bloor Street, College Street, Harbord Street, Dundas, Spadina, Queen's Park, and Bay Street. Parking is also readily available to the area with the University of Toronto having 1500 parking spaces on campus and another 2500 parking spaces found in municipal parking lots within a 15-minute walk of the facility to bring the total to 3000 potential spaces. Varsity Centre is also highly accessible via public transit as well as there are two streetcar lines (510 Spadina and 506 Carleton), while there are also 10 subway stations that fall within a 15 -minute walk from the stadium; the closest of which include Spadina, St. George, and Museum between a 27 minute walking time. Pedestrian accessibility is favourably found within the area with bike lanes having previously been installed on St. George Street, Harbord Street, Hoskin Avenue, College Street and Wellesley Street. While the site is also in close proximity to approximately 91 locations with bike racks up to 100 post and ring stands and at University of Toronto campus. Finally, the Bloor Street connection to Varsity Centre location includes wider sidewalks, appropriate street lighting and furniture, and buffered pedestrian areas that provide safety and comfort that joins the facility on the University of Toronto campus to the city.

Ultimately, when reviewing the accessibility of both stadium locales, it becomes evident that Varsity Centre is found to be more favourable in all regards besides vehicular 
accessibility and parking. However, it is adequate enough in terms of both to make it the more desirable location to place the Toronto Argonauts based on accessibility.

\subsection{Surrounding Land Use Conclusion}

In terms of the surrounding land uses assessment two measures were used to compare both facilities that included its proximity to ancillary activities and its integration into the surrounding area to see of how each stadium would potentially function in their surrounding neighbourhoods.

BMO Field is located in an identified regeneration centre within the City of Toronto, an area that is used primarily for entertainment with other large facilities within close vicinity that allow for potential patrons to be drawn to the area. However, the majority of citizens would not typically visit one before or after a three hour Toronto Argonauts game. It most be noted though, that within a 15-minute walk north in Liberty Village there are between 130-140 other establishments, that could have potential patrons visiting the area before and after a game. There is a noticeable lack of city blocks and intersection in the vicinity of BMO Field, which decreases the prospect for a visitor to experience a vibrant and diverse urban environment. It also creates a lack of sense of

place with no identity. As a result of the restricted supporting uses and negative used space, potential fans of the stadium will not be as likely to extend their experience in the surrounding area before and after games.

Whereas, Varsity Centre, being located in a visitor oriented commercial and institutional area that is developed to be highly accessible and inviting to those that will travel through the space. Traveling within a 15-minute walk in any direction, potential patrons could encounter any number of the five commercial districts, Bloor Annex, 
Bloor-Yorkville, Chinatown, Church-Wellesley, Kensington Market, and Downtown Yonge, with more than 4500 establishments. The plentiful amounts of surrounding land uses are more than likely something to draw any type of individual imaginable, providing spectators with the greatest opportunity to extend their overall experience before and after a Toronto Argonauts game in the surrounding neighbourhoods. Also, within a 15-minute walk of the stadium are an abundance of blocks in numerous shapes and sizes with many intersections splitting them up. This grid pattern encourages the movement of people in all directions and increases the likelihood to experience something new during each trip.

When concluding these last criteria, Varsity Centre is found to be superior in terms of a land use evaluation. If the franchise was to be placed at this location, it would provide a better potential to tie into the surrounding land uses to help create a more vibrant experience for those fans that are using the surrounding spaces. With more potential land uses, mixed development, and a better city block pattern will provide the greatest potential for potential patrons to serve as a better experience what the space has to offer, that is exciting and unique to experience, while partaking in an Argonauts football.

\subsection{Summary of Conclusions}

Ultimately, when attempting to answer the research question, "which stadium, BMO Field or Varsity Centre, has the greater potential to become the new home stadium of the Toronto Argonauts based on the evaluated criteria of redevelopment cost, site, accessibility, and a surrounding land use?" Varsity Centre is found to have a greater potential to be the stadium to host the Toronto Argonauts as demonstrated in the assessment performed from the proposed research question and summarized within Table 
4. From these evaluated criteria of cost to redevelop, its location within the city centre, the prospect of accessibility to the site, and its surrounding land uses Varsity Centre is found to be more adequately developed to enhance the city and potential fans experience from having the team play at this locale compared to that of BMO Field.

Table 4: Concluding Summary of Sites Based on Evaluations

\begin{tabular}{|l|c|c|}
\hline \multicolumn{1}{|c|}{ Evaluation Criteria } & BMO Field & Varsity Centre \\
\hline \multicolumn{1}{|c|}{ REDEVELOPMENT COST } & $\checkmark$ \\
\hline Financial Cost to Redevelop Current Stadium on Site & $\checkmark$ & $\checkmark$ \\
\hline Site Proximity to City Centre ACCESSIBILITY & $\checkmark$ \\
\hline Site Proximity to Client Base SUTION & $\checkmark$ \\
\hline \multicolumn{2}{|c|}{ SURROUNDING LAND USE } & $\checkmark$ \\
\hline Vehicular Accessibility and Parking & \\
\hline Public Transit Accessibility Activities & $\checkmark$ \\
\hline Pedestrian Accessibility & \\
\hline \multicolumn{2}{|c|}{ OVERALL } & $\checkmark$ \\
\hline Site Proximity to Supplementary Area & \\
\hline Site Integration into Surrounding Area & \\
\hline
\end{tabular}




\subsection{Recommendations}

Provided from the results found within the Table 4, Varsity Centre is found to be superior to BMO Field in terms of redevelopment cost, site location, accessibility, and surrounding land use evaluations, Therefore, it is with great certainty that based from the evaluations performed and conclusions provided that it would be my professional planning recommendation that Varsity Centre would be the location to relocate the Toronto Argonauts franchise to.

Furthermore, to provide additional direction to allow Varsity Centre to host the Toronto Argonauts home football games at this time, I have provided a series of specific recommendations for the City of Toronto to optimize the potential of this stadium. The following recommendations include:

- Development of a proposal for the redevelopment of Varsity Centre to host the Toronto Argonauts.

- Engage the University of Toronto and local stakeholders about the benefits of a partnership to redevelop Varsity Centre and its potential to once again host Toronto Argonaut games.

- Includes the use of on-site University of Toronto parking lots

- Promotion of historical ties between local community and team.

- Develop a system of game day vehicular routes to move traffic in and out of the area.

However, as Varsity Centre has not been definitively selected as the new host facility of the Toronto Argonauts at this time, obstacles may arise to prevent Varsity Centre from being chosen. These obstructions could come in the form of financial, political, and nimbyism that have plagued the team from playing at this stadium in recent decades. Also, MLSE may acquire the funding sources to allow them to complete a third 
phase of renovations to BMO Field. Therefore, I have provided a series of specific recommendations for the City of Toronto to optimize the potential of BMO Field to hosting Argonaut games. These will recommendations include:

- Push for the inclusion of the third phase of renovations to adequately redevelop the field dimensions stadium to host CFL games.

- Continue to direct residential, business, and mixed-use development in the vicinity of Exhibition stadium and Liberty Village that is a designated redevelopment area to increase the area's population.

- Create TTC transit routes to and from BMO Field that will serve a larger population to various regions the City of Toronto.

- Encourage pedestrian accessibility through the placement of more City of Toronto bike-share locations and post and ring stands within a 15-minute walk radius of BMO Field.

- Implement bike lanes on roadways surrounding BMO Field.

- Create better-landscaped connection and access between Exhibition GO Station, BMO Field and Liberty Village.

- Develop parking lot lands surrounding BMO Field into mixed-use development that will provide a greater overall experience to the patrons of games and bring people to the area more readily.

- Improve surrounding unbuilt lands to be more pedestrian friendly in immediate vicinity of facility. 


\section{References}

\section{Journal Articles and Books}

Badland, H., White, M.m MacAulay, G., Eagleson, S., Mavoa, S., Pett, C., and Giles Corti, B. (2013). Using simple agent-based modeling to inform and enhance neighbourhood walkability. International Journal of Health Geographics. 12(1), $58-68$.

Bain, D. (1994). The sports stadium as a municipal investment. Westport, CT: Greenwood Press.

Bennett, J. (2012). They play, you pay: Why taxpayers build ballparks, stadiums, and arenas for billionaire owners and millionaire players. New York, NY: Copernicus Books.

Burke, M. and Evans, R. (2010). Public transport access to proposed stadium sites. Journal of the Eastern Asia Society for Transportation Studies, 8, 1408-1423.

Chapin, T. (2004). Sports facilities as urban redevelopment catalysts. Journal of the American Planning Association, 79(2), 193-209.

Coates, D. and Humphreys, B. (2006). Proximity benefits and voting on stadium and arena subsidies. Journal of Urban Economics 59, 285-299.

Davies, L. (2010). Sport and economic regeneration: A winning combination? Sport in Society, 13(10), 1438-1457.

Delaney, K. and Eckstein, R. (2007). Urban Power Structure and Publicly Finaced Stadiums. Sociological Forum. 22(3), 331-353.

Duquette, G. and Mason, D. 2008. Urban regimes and sport in north american cities: Seeking status through franchises, events and facilities. International Journal of Sport Management and Marketing, 3(3), 221-241.

Friedman, M. and Mason, D. (2004). A stakeholder approach to understanding economic development decision making: Public subsidies for professional sports facilities. Economic Development Quarterly. 18(3), 236-254.

Galily, Y., Yuval, F., and Bar-Eli, M. (2012). Municipal subsidiary toward professional sports teams. International Journal of Sociology and Social Policy, 32(7/8), 431 447.

Groothius, P., Johnson, B., and Whitehead, J. (2004). Public funding of professional sports stadiums: Public choice or civic pride. Eastern Economic Journal. 30(4), 515-526. 
John, G., Sheard, R., and Vickery, B. (2007). Stadia: A design and development guide. $4^{\text {th }}$ edition. Jordan Hill, OX: Elsevier Limited.

Kemp, R. (2009). Cities and sports stadiums: A planning handbook. Jefferson, NC: MacFarland \& Company, Inc.

Lenskyj, H. (2004). Funding canadian university sport facilities. Journal of Sport and Social Issues. 28(4), 379-396.

Long, J. (2005). Full count: The real cost of public funding for major league sports facilities. Journal of Sports Economics, 6(2), 119-143.

Mason, D. (2012). Sports facilities and urban development: an introduction. City, Culture and Society, 3(3), 165-167.

Nelson, A. 2002. Locating major league stadiums where they can make a difference: Empirical analysis with implications for all major public venues. Public Works Management and Policy, 7(2), 98-114.

Newsome, T. and Comer, J. (2000). Changing intra-urban location patterns of major league sports facilities. The Professional Geographer, 52(1), 105-120.

Noll, R. and Zimbalist, A. (1997). The economic impact of sports teams and facilities in sports, jobs, and xaxes. Washington, DC: Brookings Institution Press.

Propheter, G. (2012). Are basketball arenas catalysts of economic development? Journal of Urban Affairs, 34(4), 441-459.

Rosentraub, M. (2006). The local context of a sports strategy for economic development. Economic Development Quarterly. 20(3), 278-291.

Swindell, D. and Rosentraub, M. (1998). Who benefits from the presence of professional sports teams? The implications for public funding of stadiums and arenas. Public Administration Review, 58(1), 11-20.

Thornley, A. (2002). Urban regeneration and sports stadia. European Planning Studies, 10(7), 813-818.

Yin, R. (2003). Case study research: Design and methods. $3^{\text {rd }}$ Edition. Thousand Oaks, Cal: Sage Publications, Inc.

\section{Professional Reports}

Calgary Regional Partnership. (n.d.). Walkability Catchment. Greenfield Tool Box Evaluation Metric. Calagry Regional Partnership. Retrieved from 
http://greenfield.calgaryregion.ca/tools/greenfield_process_walkabilityCatchment. pdf

City of Toronto. (2006). University of toronto secondary plan. City of Toronto, City Planning Division. Retrieved from http://www1.toronto.ca/static_files/CityPlanning/PDF/20_university_toronto_dec 2010.pdf

City of Toronto. (2010). Official plan. map 18: Land use plan. City of Toronto. Retrieved from http://www1.toronto.ca/static_files/CityPlanning/PDF/18_landuse_dec2010.pdf

City of Toronto. (2014). Staff report: Renovation and expansion of bmo field. City of Toronto. Retrieved from http://www.toronto.ca/legdocs/mmis/2014/ex/bgrd/backgroundfile67466.pdf

\section{Online Sources}

Blair, J. (2012, June 19). Fields of frustration abound in cfl. The Globe and Mail. Retrieved from http://www.theglobeandmail.com/sports/football/fields-of frustration-abound-in-cfl/article4352443/

CBC News, (2009, March 9). Molson stadium to begin \$29.4 million expansion. Canadian Broadcasting Corporation. Retrieved from http://www.cbc.ca/news/canada/montreal/molson-stadium-to-begin-29-4m expansion-1.842309

CBC News. (2013, July 23). Ford vows to find cfl's argonauts a new home. Canadian Broadcasting Corporation. Retrieved from http://www.cbc.ca/m/touch/canada/toronto/story/1.1314602

City of Toronto. (n.d.). BIA Listings and Directory. City of Toronto, Economic Development Division. Retrieved from http://www1.toronto.ca/static_files/economic_development_and_culture/docs/BI A_Maps/citywide-map.pdf

Exhibition Place. (n.d.). Visiting: Directions, Transit, and Parking. Retrieved from http://www.explace.on.ca/visiting/directions__parking/parking.php

Ferland, F. (2010, July 16). Visiting the alouettes new home. Montreal Alouettes. Retrieved from http://en.montrealalouettes.com/article/visiting-the-new-home/

Go Transit. (n.d.). Stations and Stops: Exhibition GO Station - Train Station Retrieved from http://www.gotransit.com/publicroot/en/travelling/stations.aspx?station=EXGO 
Hadden, J. (2014, September 23). BMO field expansion construction begins.

Global News. Retrieved from http://globalnews.ca/news/1578582/bmo-field expansion-constructionbegins/

Liberty Village BIA. (n.d.). Liberty Village Business Improvement Area: Business Directory. Retrieved from http://www.lvbia.com/directory/a \& http://www.lvbia.com/area-maps

Ralph, D. (2013, September 20). Toronto argonauts days at rogers centre are numbered after signing new lease. The Globe and Mail. Retrieved from http://www.theglobeandmail.com/sports/football/toronto-argonauts-daysatrogers-centre-numbered-after-signing-new-lease/article14432778/

Rubin, J. (2014, September 23). Toronto fc and mlse begin bmo field renovation. Toronto Star. Retrieved from http://www.thestar.com/sports/tfc/2014/09/23/toronto_fc_and_mlse_begin bmo_field_renovation.html

Rush, C. (2014, June 19). Argos return to varsity stadium for cfl pre-season game against ticats. Toronto Star. Retrieved from http://www.thestar.com/sports/argos/2014/06/19/argos_return_to_varsity_stadiu _for_cfl_preseason_game_against_ticats.html

Scianitti, M. (2014, September 4). Argo's players, staff grow frustrated over work conditions. The Sports Network. Retrieved from http://www2.tsn.ca/toronto/story/?id=460968

Shum, D. (2014, April 3). City council approves \$10 million financing plan to expand bmo field. Global News. Retrieved from http://globalnews.ca/news/1248064/city-council-to-debate-10-millionfundingmodel-to-expand-bmo-field/

Stinson, S. (2014a, September 23). Can mlse and a renovated bmo field save the toronto argos? National Post. Retrieved from http://sports.nationalpost.com/2014/09/23/can-mlse-and-a-renovated-bmofieldsave-the-toronto-argos/

Stinson, S. (2014b, October 19).Toronto argonauts' attendance woes just one of the problems franchise is facing. National Post. Retrieved from http://news.nationalpost.com/2014/10/19/toronto-argos-are-a-franchise struggling-to-stay-afloat/

Toronto.com. (n.d.). Exhibition Place. Retrieved from http://www.toronto.com/things-to-do/exhibition-place 
Toronto Argonauts. (n.d.a). Stadium History.

Retrieved from http://www.argonauts.ca/page/stadium-history

Toronto Argonauts. (n.d.b). Year by Year History. Retrieved from http://www.argonauts.ca/page/year-by-year-history

Toronto FC. (2014, September 23). Bmo field renovation officially underway.

Toronto Football Club. Retrieved from

http://www.torontofc.ca/news/2014/09/bmo-field-renovation-officiallyunderway

Toronto Neighbourhood Guide. (n.d.a). Downtown Liberty Village: Welcome to Liberty Village. Retrieved from

http://www.torontoneighbourhoods.net/neighbourhoods/downtown/liberty-village

Toronto Neighbourhood Guide. (n.d.b). Downtown South Annex: Welcome to South Annex. Retrieved from

http://www.torontoneighbourhoods.net/neighbourhoods/downtown/south-annex

Toronto Neighbourhood Guide. (n.d.c). Midtown Annex: Transportation in Annex.. Retrieved from http://www.torontoneighbourhoods.net/neighbourhoods/midtown/annex/transport ation

Toronto Neighbourhood Guide. (n.d.c). Midtown Annex: Transportation in Annex. Retrieved from http://www.torontoneighbourhoods.net/neighbourhoods/midtown/annex/transport ation

University of Toronto. (n.d.a) Directions to U of T St. George. Retrieved from http://start.utoronto.ca/essential-u-of-t/directions/

University of Toronto. (n.d.b). Transportation Services: Your Guide to Getting Around St. George Campus. Retrieved from http://www.transportation.utoronto.ca

\section{Online Databases and Images}

City of Toronto. (2013). 2013 Property Data Maps. Ryerson Library and Archives. Geospatial Map and Dada Centre. Retrieved from $\mathrm{http}$ ://gis.ryerson.ca/pdm_toronto/pdmindex.htm

Google Earth. (2015a). "BMO Field”

Google Earth. (2015b). "Varsity Centre"

Google Maps. (2015a). BMO Field to Downtown Toronto. Google Search. Retrieved From 
https://www.google.ca/maps/dir/BMO+Field,+170+Princes'+Boulevard,+Toronto ,+ON+M6K+3C3/43.6505045,-79.3779838/@43.6413909,-

$79.4388022,13 \mathrm{z} /$ data $=$ !4m9!4m8! $1 \mathrm{~m} 5 ! 1 \mathrm{~m} 1$ ! $1 \mathrm{~s} 0 \mathrm{x} 882 \mathrm{~b} 350 \mathrm{f} 5 \mathrm{~b} 7 \mathrm{~b} 2773: 0 \mathrm{xe} 0993 \mathrm{f} 68$

3b9eb98d!2m2!1d-79.418909!2d43.632711!1m0!3e0

Google Maps. (2015b). Varsity Centre to Downtown Toronto. Google Search. Retrieved from

https://www.google.ca/?gws_rd=ssl\#q=distance+from+varsity+centre+to + downto wn+toronto

Municipal Parking. (n.d.a) Find Parking By Address - 170 Princes’ Boulevard. Municipal Parking Official Website. Retrieved from http://parking.greenp.com/find-parking/

Municipal Parking. (n.d.b) Find Parking By Address - 290 Bloor Street West. Municipal Parking Official Website. Retrieved from http://parking.greenp.com/find-parking/

Simply Map 3.0. (2015a) BMO Field. 170 Princes' Boulevard, Toronto Ring Study.

Simply Map 3.0. (2015b). Varsity Centre. 290 Bloor Street West, Toronto Ring Study.

Walk Score. (2015a). 170 Princes'Boulevard. Walkscore.com. Retrieved from https://www.walkscore.com/score/170-princes\%27-blvd-toronto-on-canada

Walk Score. (2015b). 290 Bloor Street West. Walkscore.com. Retrieved from https://www.walkscore.com/score/290-bloor-st-w-toronto-on-canada 